Diabetologia 3, 266-286 (1967)

\title{
Diabetes Mellitus in the Chinese Hamster
}

\section{The Evolution of Renal Glomerulopathy}

\author{
Takeshi Shirai*, George W. WerLin, 3rd, and Ethan A.H. Stms
}

\author{
Metabolic Unit, Department of Medicine, College of Medicine, University of Vermont, Burlington, Vermont
}

Summary. Light and electron microscopic studies were made of the renal glomeruli of 11 control Chinese hamsters, 4 siblings of diabetic hamsters, and 6 with spontaneous diabetes of varying age of onset, duration, and severity. Aging alone was associated with an increase in mesangial matrix and some degree of capillary dilatation and thickening of the basement membrane. In severe diabetes of early-onset, there was a marked change in mesangial cells, consisting of an increase in vesicles, multivesicular bodies, vacuoles, ghost-like appearance of the cytoplasm, and mitochondrial disorganization. Only in the more advanced stages was there an increase in the mesangial matrix. Initially, the basement membrane was thin, particularly in dilated capillaries. Measurements of the basement membrane in the later stages indicated that there were both thick and thin areas; increased thickness alone was not characteristic. Although similar findings developed progressively with age, mesangial cell alterations, coalescence and cystic dilatation and fusion of capillary loops in the glomeruli of young hamsters were characteristic findings of diabetic glomerulopathy. These findings were characteristic and disproportionately marked in any later stage of the disease. Coalescence of capillaries may have explained the decrease in the number of loops. The foot processes of the epithelial cells were well-preserved in all glomeruli and nodular lesions were not seen. There was no evidence in this series that litter-mates of diabetic animals deveIoped such glomerular lesions in the absence of overt diabetes. An analogy was suggested between the dilatation and coalescence of glomerular capillaries associated with mesangial cell changes and the dilatation of retinal capillaries associated with degeneration of the supporting mural cells in man.

Diabète sucré chez le hamster chinois: II. L'évolution de la glomérulopathie rénale.

Résumé. Nous avons étudié aux microscopes optique ot électronique les glomérules rénaux de 11 hamsters chinois non-diabétiques, de 4 hamsters non-diabétiques mais provenant de nichées comportant des animaux diabétiques, et de 6 animaux ayant souffert d'un diabète de durée et de sévérité variables. Le vieillissement en soi est associé à une augmentation du mésangium et à une dilatation des capillaires avec léger épaississement de la membrane basale. Chez les diabétiques sévères de type juvénile, nous avons observé des altérations profondes des cellules mésangiales, avec la formation de vésicules, de corps multivésiculaires, de vacuoles et une apparence lavée du cytoplasme avec désorganisation mitochondriale. Ce n'est qu'aux stades les plus avancés qu'on observe une augmentation de la matrice mésangiale. Aux premiers stades, les membranes basales sont minces, particulièrement pour les capillaires dilatés. A des stades plus avancés, on trouve des régions épaisses et des régions minces de la membrane basale; certainement pas d'épaississement généralisé. Bien que des altérations semblables eussent été observées avec le vieillissement simple, les altérations des cellules mésangiales, la

* Present address: 3rd Department of Internal Medicine, Faculty of Medicine, Kyushu University, Katakasu, Fukuoka, Japan. coalescence, la dilatation cystique et la fusion des anses capillaires des glomérules sont caractéristiques d'une glomérulopathie diabétique chez les animaux jeunes. Les altérations sont beaucoup plus marquées à des stades plus avancés de l'état diabétique. La diminution du nombre des anses capillaires est probablement le résultat de la coalescence des capillaires. Les cellules épithéliales sont bien préservées dans tous les glomérules et il n'y a pas de lésions nodulaires. Nous n'avons pas observé de lésions glomérulaires semblables chez les frères et soeurs des animaux diabétiques ne souffrant pas eux-mêmes d'un diabète patent. Il semblerait y avoir une analogie entre la dilatation et la coalescence des capillaires du glomérule en présence d'altérations des cellules mésangiales et la dilatation des capillaires rétiniens associée à la dégénérescence des cellules murales, ou péricytes, chez l'homme.

Diabetes mellitus beim chinesischen Hamster: II. Der Verlauf der renalen Glomerulopathie.

Zusammenfassung. Wir haben im Licht- und im Elektronen-Mikroskop die renalen Glomeruli von 11 Kontrolltieren, von 4 nicht-diabetischen. Tieren aus gleichem Wurf wie diabetische Hamster, und von 6 Tieren mit Spontan-Diabetes verschiedenen Alters, sowie mit unterschiedlicher Dauer und Schwere des Krankheitsbildes, untersucht. Zunehmendes Alter führte zur Zunahme der mesangialen Matrix mit einiger Erweiterung der Kapillaren und Verdickung der Basalmembran. Bei früh einsetzendem schweren Diabetes wurden schwere Veränderungen der Mesangialzellen beobachtet, bestehend aus Vermehrung der vesikulären Bläschen, Entstehung von multi-vesikulären Strukturen, Vacuolen, und einem verwaschenen Aussehen des Zytoplasmas, sowie mit. ochondrialer Desorganisation. Bei vorgerücktem Krankheitsbild bestand eine deutliche Zunahme der mesangialen Matrix. Anfänglich war die Basalmembran dünn, besonders in den erweiterten Kapillaren. Später, wies die Basalmembran sowohl verdickte wio verdünnte Stellen auf. Obwohl ähnliche Veränderungen auch mit zunehmendem Alter zu sehen waren, ließ die Beobachtung von Veränderungen der mesangialen Zellen, von zystischer Erweiterung und Verschmelzen von Kapillarschlingen. bei jungen Hamstern sicher auf diabetische Glomerulopathie schließen. Diese Veränderungen waren denn auch verhältnismäßig noch deutlicher und besonders charakteristisch in späteren Stadien der Krankheit. Die Fusion von Kapillaren erklärt vielleicht die Abnahme der Zahl der Kapillarschlingen. Die Ausläufer der Epithelialzellen blieben in allen Glomeruli wohl erhalten und es waren keine noduläre Läsionen zu sehen. In den von uns beobachteten Tieren waren solche Veränderungen der Glomeruli bei nicht-diabetischen Tieren nicht zu sehen. Es wird darauf hingewiesen, daß zwischen der Erweiterung und der Fusion von Kapillarschlingen, im Zusammenhang mit Veränderung der mesangialen Zellen, und der Erweiterung von Kapillaren der Netzhaut, im Zusammenhang mit Degeneration deren Perizyten beim Menschen, eine Analogie besteht.

Key-words: Spontaneous Diabetes, Chinese hamster, Cricetulus griseus, Kidney, Renal glomerulopathy, Capillaries, Basement membrane, Ultrastructure, Mesangium. 
Heretofore many investigations have been designed to elucidate the nature and evolution of diabetic glomerulopathy in animals made chronically deficient in insulin by alloxan or anterior pituitary extract treatment or by pancreatectomy. However, the diabetes produced may not be comparable with the spontaneous form commonly found in man.

In 1959 Meier and Yerganian [35] reported the development of spontaneous diabetes in a strain of Chinese hamsters upon inbreeding. The disease appeared to be quite similar to so-called juvenile diabetes in man, in that islet hypertrophy and hypersecretion of insulin have not been demonstrated. It was not inducible by changes in diet and was not accompanied or preceded by obesity. (In a companion deficiency and hence similar to the iatrogenic disease in other animals. However, the disease in the Chinese hamster was felt to represent a naturally-occurring disorder and might therefore provide evidence as to the evolution of renal glomerular lesion in animals and perhaps in man. This report summarizes our light and electron microscopic findings in a number of nondiabetic and diabetic Chinese hamsters.

\section{Methods and Materials}

Twenty-one Chinese hamsters ${ }^{1}$ (Cricetulus griseus) were divided into 4 groups and one subdivision depending on their metabolic and genetic status as follows (see Table 1).

Table 1. Summary of Experimental Animals

\begin{tabular}{|c|c|c|c|c|c|c|c|}
\hline Group & $\begin{array}{l}\text { Exper. } \\
\text { no. }\end{array}$ & Sex & $\begin{array}{l}\text { Age } \\
\text { (months) }\end{array}$ & $\begin{array}{l}\text { duration } \\
\text { of } \\
\text { diabetes } \\
\text { (months) }\end{array}$ & $\begin{array}{l}\text { Body } \\
\text { wt. } \\
\text { (grams) }\end{array}$ & $\begin{array}{l}\text { Glucosuria } \\
\text { mg/day }\end{array}$ & $\begin{array}{l}\text { Blood } \\
\text { glucose } \\
\text { mg 100mal }\end{array}$ \\
\hline \multirow[t]{2}{*}{$\begin{array}{l}\text { Non-diabetic A) } \\
\text { Hamsters }\end{array}$} & $\begin{array}{l}8-2 \\
C U V-C \\
C U V-1 \\
C U V-2 \\
33^{5} \\
22 \\
E\end{array}$ & $\begin{array}{l}\mathrm{F} \\
\mathrm{M} \\
\mathrm{F} \\
\mathrm{F} \\
\mathrm{F} \\
\mathrm{F} \\
\mathrm{M}\end{array}$ & $\begin{array}{r}8 \\
16 \\
17 \\
17 \\
28 \\
30 \\
38\end{array}$ & & $\begin{array}{l}29 \\
34 \\
30 \\
22 \\
22 \\
24 \\
40\end{array}$ & $\begin{array}{l}- \\
- \\
- \\
- \\
-\end{array}$ & $\begin{array}{l}113 \\
156 \\
100^{1} \\
114 \\
- \\
143 \\
165\end{array}$ \\
\hline & $\begin{array}{l}\mathrm{CS}-\mathrm{E} \\
\mathrm{CS}-4 \\
\mathrm{CS}-1 \\
\mathrm{CS}-3\end{array}$ & $\begin{array}{l}\mathrm{M} \\
\mathrm{F} \\
\mathrm{F} \\
\mathrm{F}\end{array}$ & $\begin{array}{r}9 \\
13 \\
16 \\
25\end{array}$ & & $\begin{array}{l}29 \\
29 \\
25 \\
25\end{array}$ & $\begin{array}{l}- \\
- \\
-\end{array}$ & $\begin{array}{l}- \\
238 \\
160 \\
102\end{array}$ \\
\hline $\begin{array}{l}\text { Non-diabetic } \\
\text { littermates } \\
\text { of diabetic } \\
\text { hamsters }\end{array}$ & $\begin{array}{l}6-2 \\
37 \\
B-1^{5} \\
38\end{array}$ & $\begin{array}{l}\mathrm{F} \\
\mathrm{F} \\
\mathrm{F} \\
\mathrm{F}\end{array}$ & $\begin{array}{l}13 \\
18 \\
18 \\
24\end{array}$ & & $\begin{array}{l}28 \\
25 \\
29 \\
30\end{array}$ & $\begin{array}{l}- \\
- \\
-\end{array}$ & $\begin{array}{l}131^{2} \\
-{ }^{3} \\
114^{3} \\
140^{3}\end{array}$ \\
\hline $\begin{array}{l}\text { Hamsters } \\
\text { with early- } \\
\text { onset } \\
\text { diabetes }\end{array}$ & $\begin{array}{l}\text { Severe } \\
\mathrm{C}-3 \\
\mathrm{D}-2^{5} \\
2-2\end{array}$ & $\begin{array}{l}\mathrm{M} \\
\mathbf{M} \\
\mathbf{F}\end{array}$ & $\begin{array}{r}8 \\
17 \\
23\end{array}$ & $\begin{array}{r}7 \\
16 \\
22\end{array}$ & $\begin{array}{l}22 \\
22 \\
30\end{array}$ & $\begin{array}{l}++++ \\
++++ \\
++++\end{array}$ & $\begin{array}{l}400 \\
400 \\
\mathbf{5 1} 5^{4}\end{array}$ \\
\hline \multirow{3}{*}{$\begin{array}{l}\text { Hamsters } \\
\text { with inter- } \\
\text { mediate and } \\
\text { late-onset } \\
\text { diabetes }\end{array}$} & $\begin{array}{l}\text { Mild } \\
B-2^{5} \\
\text { Severe }\end{array}$ & $\mathbf{M}$ & 18 & 1.2 & 29 & $\begin{array}{l}15-410 \\
\text { Av. } 180\end{array}$ & 235 \\
\hline & CUV $-A^{5}$ & $\mathbf{M}$ & 8 & 4 & 35 & $\begin{array}{l}150-1290 \\
\text { Av. } 880\end{array}$ & $528^{4}$ \\
\hline & 36 & $\mathrm{~F}$ & 22 & 1.2 & 29 & $\begin{array}{l}1550-1800 \\
\text { Av. } 1660\end{array}$ & 590 \\
\hline
\end{tabular}

1120 units of NPH insulin was injected over a 2-month period prior to study.

2 Litter-mate of diabetic hamster $\mathrm{D}-2$.

3 Litter-mate of diabetic hamster 36.

4 NPH insulin 2-4 units per day prior to study.

5 Metabolic studies of these hamsters are reported in the first paper of this series (SIms and LANDAU, 1967).

paper, SIMS and LANDAU [45] have reported metabolic studies on a number of the hamsters included in the present study.) Prior to the present symposium a number of functional and morphologic changes have been reported by many workers $[36,37,31,17,34,48,49]$ in pancreas, liver, adipose tissue, and kidney of those animals. The findings from the metabolic studies of these animals were consistent with chronic insulin

\section{Non-diabetic hamsters (11 animals)}

Group $A$ : Seven of this group came from the YERgantan lines HG, AS-3, and VSY. They had no glucosuria at any time during their lives and the blood

1 The Chinese Hamsters were obtained from the laboratory of Dr. G. A. YaRGANIAN, the Cancer Research Institute of Children's Hospital Medical Center, Harvard Medical School, Boston, Massachusetts. 
glucose levels ranged between $100-165 \mathrm{mg}$ per $100 \mathrm{ml}$. Although these hamsters had a family history of diabetes, there were no diabetic parents or siblings. The age range was from 8 to 28 months.

Group $B$ : This group of 4 non-diabetic hamsters came from the YERGANIAN lines 8-Aa-5 and 7-D-5, which had been free of diabetes in all known generations. These animals also had no glucosuria and were normoglycemic. The age range was from 8 to 25 months.

\section{Non-diabetic litter-mates of diabetic hamsters (4} animals).

These hamsters were non-diabetic litter-mates of the diabetic hamsters used in this experiment. The age range was from 13 to 24 months. From hamster \#37 renal tissue was obtained first by biopsy and later by autopsy when sacrificed 24 hours after water diuresis following loading with a 10 per cent sucrose solution.

III. Hamsters with early-onset diabetes (3 animals). These hamsters came from the lines HG, AS-3 and VSY. At the age of 1 to 2 months they showed severe to moderate glucosuria, which persisted but fluctuated in amount throughout their lives. No proteinuria was detected at any stage of the disease. Hyperglycemia was in the range of $400-500 \mathrm{mg}$ per $100 \mathrm{ml}$. The age range was from 8 to 23 months, and the duration of the diabetes was between 7 and 22 months.

IV. Hamsters with intermediate and late-onset diabetes ( 3 animals).

These hamsters were from the same line as those with early-onset diabetes, but one animal became diabetic at the age of 7 months and another at 20 months. The duration of diabetes was one to four months, respectively. Again, no proteinuria was detected. All diabetic animals had polyuria. Urine volume of control animals was $1-2 \mathrm{ml}$ per day, of the hamster with mild diabetes (B-2) $2-5 \mathrm{ml}$ per day, and of the others with severe diabetes from 15 to $42 \mathrm{ml}$ per day.

To evaluate the effect of insulin alone, one nondiabetic hamster (CUV-1) was given a total of 120 units of NPH insulin during a 2-month period before being sacrificed. Diabetic hamsters $2-2$ and CUV-A also received NPH insulin briefly at one time.

All hamsters were killed by intraperitoneal nembutal anesthesia. The kidneys were removed and fixed in formalin, embedded in paraffin, and stained with hematoxylin-eosin, PAS, and Congo-red. Some of the kidney tissues were sectioned after quick-freezing and stained for fat with Sudan black and oil red (8-2, C-3, and $\mathrm{E})$. At the same time samples of kidney tissue were fixed in 2 per cent cold $\left(4^{\circ} \mathrm{C}\right)$ Palade's buffered osmium-tetraoxide and embedded in Araldite for thin and ultrathin sectioning by Porter-Blum ultramicrotome. The thin sections for light microscopy were cut about one micron in thickness and stained with methylene blue and toluidine, Giemsa's stain, and a modification of Gomori's methamine-silver nitrate stain.
The ultra-thin sections for electron microscopy were stained with uranyl acetate and examined with a Phillips EM $100 \mathrm{~B}$ electron microscope.

\section{Results}

\section{Light microscopic findings}

A. Non-diabetic hamsters. In general the glomeruli of the kidneys from this group (both subdivisions A and B) had a mild degree of intercapillary glomerulosclerosis, which increased gradually with age. Specifically, PAS-positive material increased in the axial area with age, the deposition accelerating after the age of about 25 months. The number of nuclei in the glomeruli changed little before the age of about 25 months, although some pyknosis of the nuclei in mesangial cells appeared in the aging hamster. After about 25 months of age, however, the number of nuclei did increase, particularly in the mesangial cells, and other degenerative changes, such as fibrosis and pyknosis of nuclei, were accelerated. A mild degree of capillary dilatation was noted in the aged hamsters. The thickness of the basement membrane of the glomerular capillaries increased slightly in the old hamsters.

There was no obvious difference in the glomeruli between the non-diabetic hamster that received insulin (CUV-1) and the non-diabetic hamsters of comparable age. However, the mesangial area and the basement membrane of the glomeruli of hamster CS-4 differed in that they were thickened as compared with the other non-diabetic hamsters of comparable age, giving the appearance of the glomerulus in an aged nondiabetic hamster or one that was otherwise diseased.

The vascular configuration of the glomerulus in a young, non-diabetic hamster (8-2) did not differ essentially from that described in rats or mice, based upon serial thin sections and their reconstruction models of half of a glomerulus (Fig. 1 and 2, left side). The afferent arteriole entered into the Bowman's capsule and divided into several major loops that made a lobule of the glomerulus. Each loop of the capillary was also subdivided into multiple loops within the lobule. These markedly winding loops were successively recombined to form the efferent arteriole and numerous anastomoses joined the loops (Fig. 2).

B. Non-diabetic litter-mates of diabetic hamsters. The findings did not differ significantly from the nondiabetic hamsters of comparable age.

C. Hamsters with early-onset diabetes. The size of the glomeruli was increased and marked capillary dilatation was present in comparison with non-diabetic hamsters of comparable age. The number of capillary loops was apparently reduced, and there were no compressed loops seen in the dilated glomeruli. In the early stage the number of nuclei, especially in the mesangial cells, was reduced together with a decrease in the amount of PAS-positive material; the basement membrane was not thickened (Fig. 3). In the intermediate 
stage of early-onset diabetes, there was now evidence of an increase in PAS-positive material in the mesangium area (Fig. 4). In the late stage, the number of mesangial cells increased together with an increase of mesangial matrix and dilatation of capillary loops. Parts of the basement membrane had become thick and other parts in dilated capillaries were still thin (Fig. 5). The vascular structure of the early stage of early-onset diabetes was quite unique and very different from that in the young non-diabetic hamster (8-2). The capillary loops were seemingly reduced in
Fully developed Kimmelstiel-Wilson nodules were not seen at any stage of the disease, despite marked thickening of the mesangium. Moreover, the changes of acute or chronic pyelonephritis were not evident anywhere in the kidney of diabetic hamsters.

\section{Electron microscopic findings}

A. Non-diabetic hamsters. The glomeruli of a young hamster did not differ from the glomeruli of other animals, which have been described by many investigators $[47,30,14,41,28]$. The epithelial cells had fine foot

Fig. 1. Reconstruction model of half a glomerulus in an 8-month-old, non-diabetic hamster, No. 8-2 (left), and a hamster with early-onset diabetes in the early stage, $\mathrm{C}-3$ (right), based upon serial thin sections. The glomerular capillary of the diabetic hamster is dilated, but it is not aneurysmal. Scale: 1 micron $=12$ millimeters

Fig. 2. An imaginary schematic stereogram of a glomerulus in a young, non-diabetic hamster (left) and one in a hamster with early-onset diabetes in the early stage (right). The capillary loops are reduced and cystic dilatation, caused by coalescence or fusion of loops, is shown in the glomerulus of the diabetic hamster

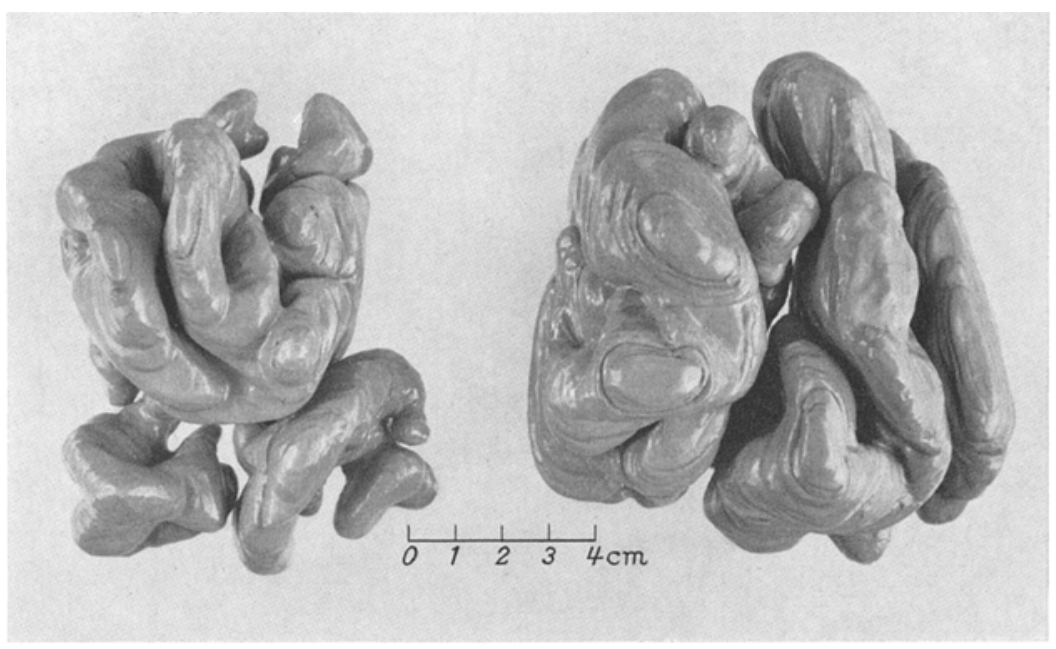

number and dilatation was present, particularly in the peripheral portion. This dilatation was not aneurysmal or balloonlike but rather cystic in nature and seemed to represent a coalescence or fusion of capillary loops (Fig. 1 and 2, right side).

D. Hamsters with intermediate and late-onset diabetes. The glomeruli of these hamsters also showed a decrease in the number of nuclei and dilatation of capillary loops together with the increase in mesangial matrix that was found in the non-diabetic hamsters of comparable age. processes, the endothelial cells had also fine pores in the peripheral portion, and the mesangial cells were neatly embedded in the mesangial matrix and were not in direct contact with the capillary lumen. The peripheral basement membrane was thin and fairly uniform, although a few of them showed a slightly "mossy" appearance (Fig. 6, 7, 8).

With advancing age there was an increase in the amount of mesangial matrix, which seemed to contain fine fibrinous structures. Alterations of the mesangial cells (such as increased vesicles, multivesicular bodies 
and vacuoles) developed, with pseudopod formation. There was also a mild degree of capillary dilatation, thickening of the basement membrane, and an increase in the "mossy" appearance. The endothelial and epithelial cells were relatively well-preserved even in the aged animal, although some degree of vacuolization, fusion of foot processes and adhesion of epithelial cells was present (Fig. 6, 8, 9).



Fig. 3. A glomerulus of the kidney of a hamster with early-onset diabetes in the early stage (C-3). The capillaries are dilated, also the number of mesangial cell nuclei and the mesangial area are decreased. Bar $=100 \mu$

Again, no differences were seen in the glomeruli of the hamster that received insulin (CUV-1) as compared with the glomeruli of the non-diabetic hamsters of comparable age (CUV-2 and litter-mates of CUV-1). The changes in the glomeruli of hamster CS-4 were different from those seen in other non-diabetic hamsters of comparable age, in that the mesangial matrix was increased and the basement membrane was thickened and had a mossy appearance.

B. Non-diabetic litter-mates of diabetic hamsters. The findings did not differ significantly from the other nondiabetic hamsters of comparable age.

C. Hamsters with early-onset diabetes. In the early stage, marked mesangial alterations (increase in the number of vesicles, multivesicular bodies and vacuoles, disorganization of mitochondria, and a ghost-like appearance of the cytoplasm) developed. Additional findings included: 1 . a dissociation of the mesangium and the basement membrane with apparent coalescence or fusion of capillary loops; 2 . marked cystic dilation of the capillary loops; 3 . a decreased number of mesangial cell nuclei; 4. profuse pseudopod formation of mesangial cells; 5. many small, round, electron-dense particles (presumably lipid) and many vacuoles in the capillary lumen. The endothelial cells showed vacuolization and microvilli formed in the cytoplasm, but the pores in the peripheral portion of these cells were

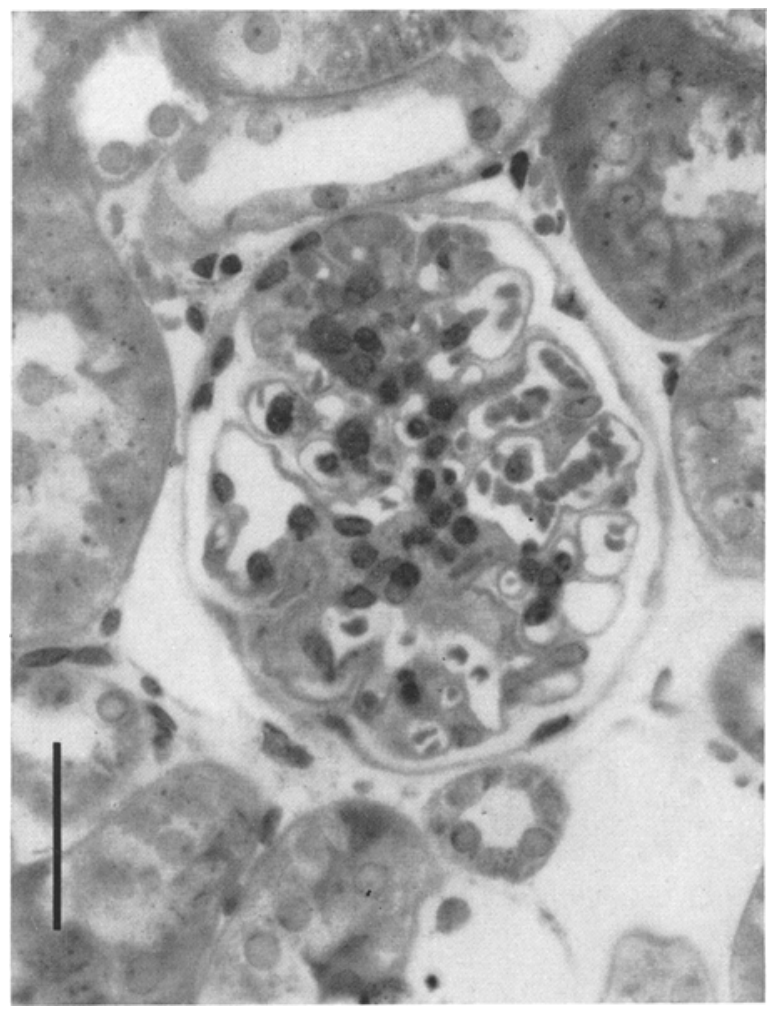

Fig. 4. A glomerulus of the kidney from the hamster with early-onset diabetes in the intermediate stage (D-2). The changes seen earlier (Fig. 3) have become more marked with increased PAS-positive material in the mesangial area. $\mathrm{Bar}=100 \mu$

clearly seen. The epithelial cell foot processes were well preserved. The basement membrane was thin and, on the epithelial side, often had the "mossy" appearance (Fig. 6, 10, 11 and 12) previously described.

More marked changes were noted in the intermediate phase. In addition there was an increased amount of mesangial matrix. The basement membranes in some areas were thin and in others thick, and some showed the "mossy" structure described above (Fig. $6,13,14$ and 15 ).

In the late stage of early-onset diabetes there was an increase in both the number of mesangial cells and the amount of mesangial matrix as well as the previously described alterations of the mesangial cells and cystic dilatation of the capillaries. Occasionally the small capillary lumen was filled with heavy homogenous material of relatively high density, a finding that has been interpreted by others as exudative changes in the glomeruli. Again the basement mem- 
brane thickness varied from place to place, some were thick and some thin, and some again showed the "mossy" structure. Occasionally, fine-grained, glasslike struetures (or very fine fibrinous material) and relatively small, round, heavy, dense material (possibly lipid) were seen in the peripheral portion of the subendothelial cell layer or between these cells and the basement membrane (Fig. 6, 16, 17 and 18).

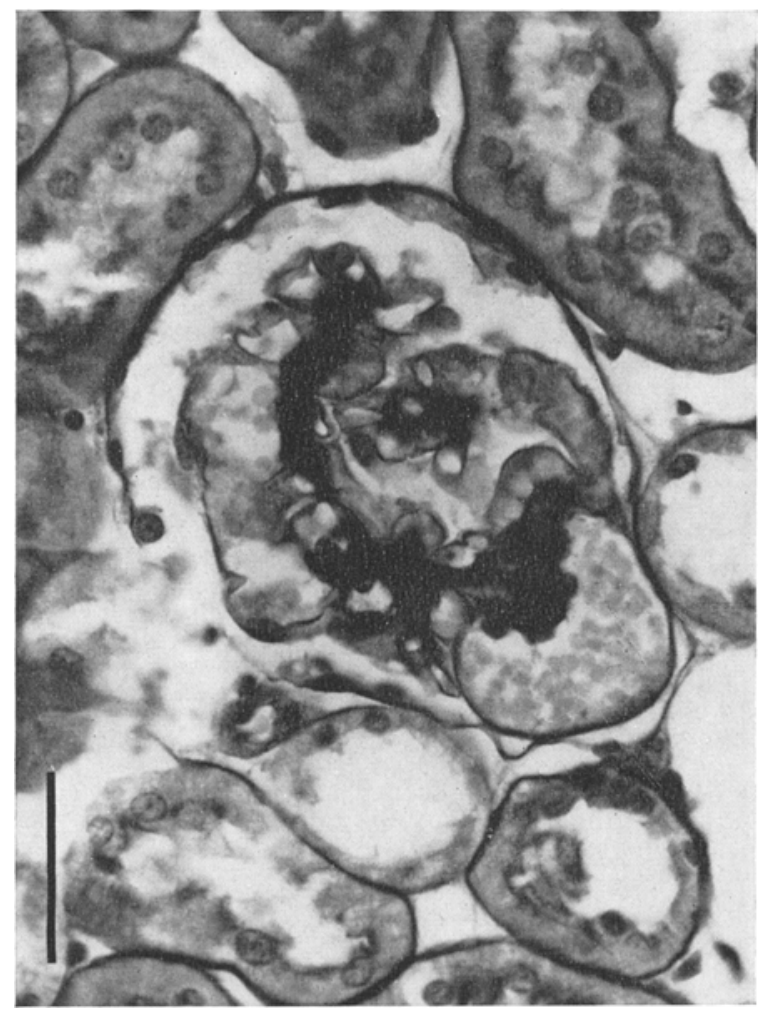

Fig. 5. A glomerulus from the hamster with early-onset diabetes in the late stage (2-2). Note the increase in the number of nuclei and the thickening of the mesangial area. Bar $=100 \mu$

D. Hamsters with intermediate and late-onset diabetes. The mesangial matrix was increased and also fibrinous structures appeared in the matrix together with the changes described in the early phase of early-onset diabetes: decreased number of mesangial cells, various mesangial alterations, and cystic capillary dilatation (Fig. 6 and 19).

Hamster B-2 was of particular interest since he was shown to have well documented but mild diabetes, without polyuria. The changes in the glomeruli were of the same nature, including capillary dilatation and coalescence, as those of the late-onset hamsters of comparable age with severe diabetes, but were of lesser severity, and osmophilic deposits were not seen in the capillary lumen. The changes exceeded those due to age alone in hamsters of comparable age without diabetes, but in view of the age it is impossible to say how much of the pathology may have been due to diabetes alone.
E. Thickness of the basement membrane. Three hundred random measurements of the basement membrane were made at the periphery of the glomerular loops in each of 3 non-diabetic hamsters, in 4 nondiabetic litter-mates of diabetic hamsters, in 3 hamsters with early-onset diabetes, and in 1 hamster with lateonset diabetes. The distribution curve of thickness in the non-diabetic hamsters was approximately bell shape, with the apex shifting towards increase in thickness with increasing age (Fig. 20). Non-diabetic littermates of diabetic hamsters showed virtually the same curve as the non-diabetic hamsters of comparable age (Fig. 21 and 22). There were slight but non-significant differences in the mean thickness of the basement membranes in tissues obtained by biopsy before diuresis $(2020=$ S. D. $710 \AA)$ and those obtained by autopsy after water diuresis $(1620=\mathrm{S} . \mathrm{D} .710 \AA)$ in the same hamster (No. 37).

The distribution curve of the thickness of the basement membrane in the hamsters with early-onset diabetes showed a variable shape (Fig. 20). There was only a single peak but the mean was shifted toward thin values with some increase in thick values as well. The curve of the intermediate and late stages differed markedly from that of the non-diabetic hamster of comparable age in becoming biphasic, with a secondary grouping of thicker measurements. The major peak of thickness in the late stage showed less thickness than the intermediate phase of the diabetic hamster. The distribution curve of late-onset diabetic hamster also showed two peaks, but the major peak point was at lesser thickness than in the non-diabetic hamster at age 18 months (Fig. 22).

\section{Discussion}

The similarity of the findings between diabetic glomeruloselerosis and the aging process in man has been previously noted [22, 23]. Since Arataki [4] demonstrated loss of glomeruli in the senile albino rat, many investigators have studied the aging process of the glomeruli in experimental animals, including Chinese hamsters, $[37,3,5,18,19,27,32]$ by means of light microscopy. In general, it is agreed that intercapillary glomerulosclerosis or thickening of the axial area, thickening of the basement membrane, some degree of capillary dilatation, and reduction of the number of nuclei in the glomeruli oceur in the aging process.

We agree with the observations of other investigators regarding the nature of the changes characteristic of aging, but we note that such changes progressed only gradually before the age of 25 months and accelerated thereafter. Such changes included also vacuolization of the mesangial cells, the inclusion of vesicles and multivesicular bodies, and an increase in the mesangial matrix. The significance of these changes in the mesangial cells is not known.

Glomerulopathy associated with experimentallyinduced diabetes mellitus in animals has been studied by many investigators using both light and electron 

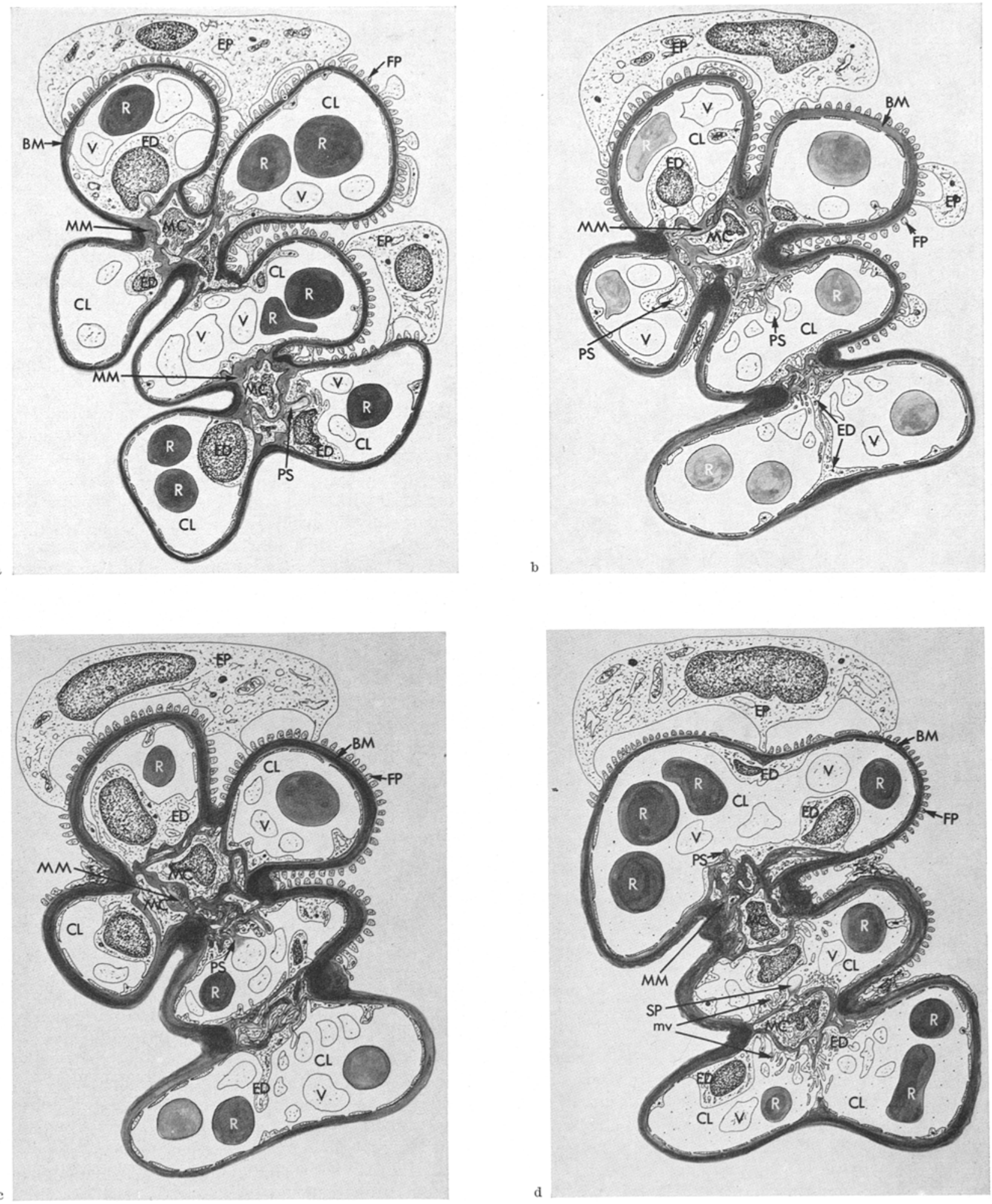

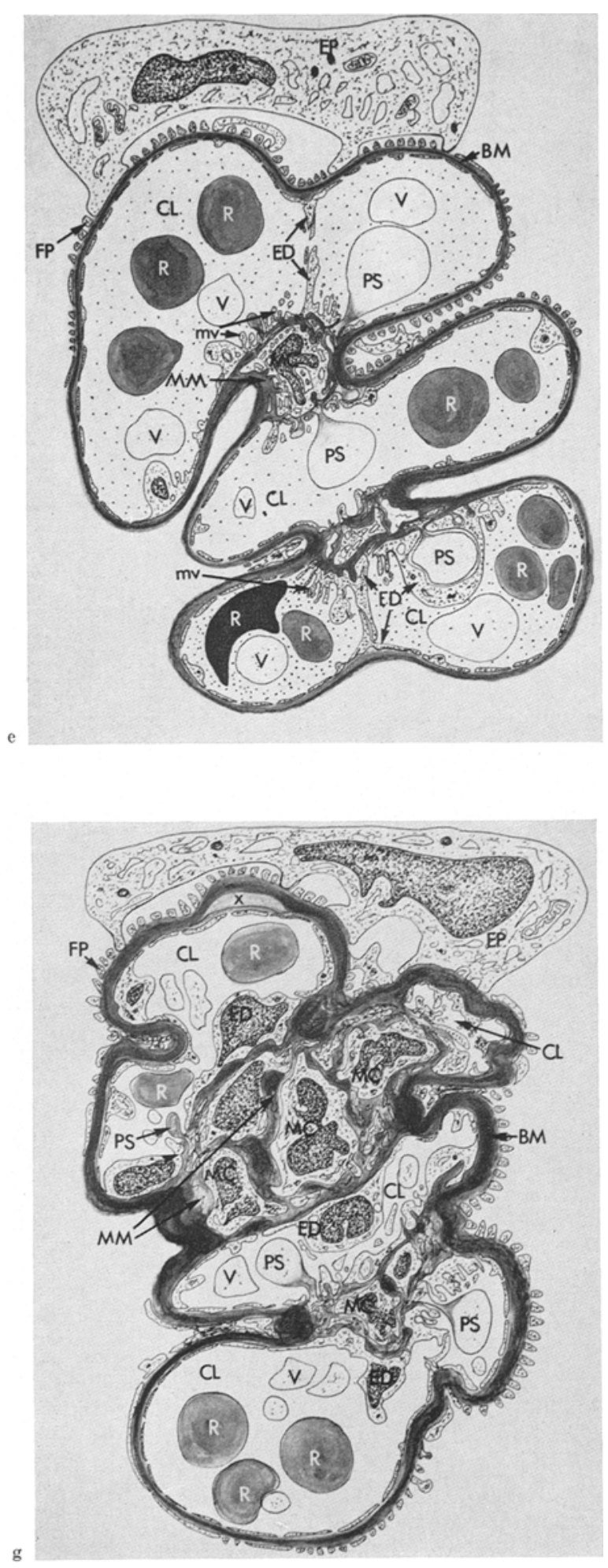

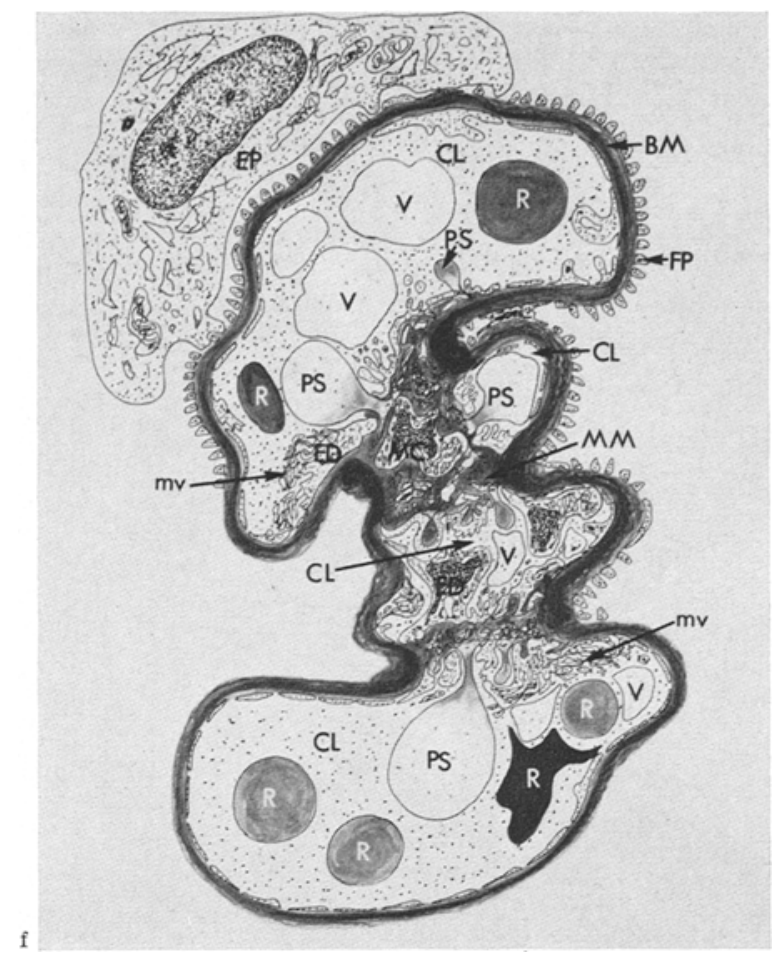

Fig. 6. A schematic illustration of glomeruli from the results of electron microscopic studies. Drawings a to $\mathrm{c}$ indicate changes subsequent to aging of the non-diabetic hamster, $a$ is a glomeruhs of a young hamster and $c$ is a glomerulus of an old hamster. e to g show progressive changes occurring in the hamster with early-onset diabetes. $e$ is an earlier lesion and $g$ is a late stage of the disease. $d$ shows the changes in the glomerulus of the hamster

Legend:

BEP: Epithelial cell of Bowman's capsule

BM: Basement membrane

BS: Bowman's space

CL: Capillary lumen

Ex: Exudative changes

FD: Endothelial cell

Ep: Epithslial cell

$$
\text { with late-onset diabetes }
$$

FP: Foot processes of epithelial cell

MC: Mesangial cell

MM: Mesangial matrix

mv: Microvilli formation of endothelial cell

PS: Pseudopod of mesangial cell

R: Red blood cell

V: Vacuoles 


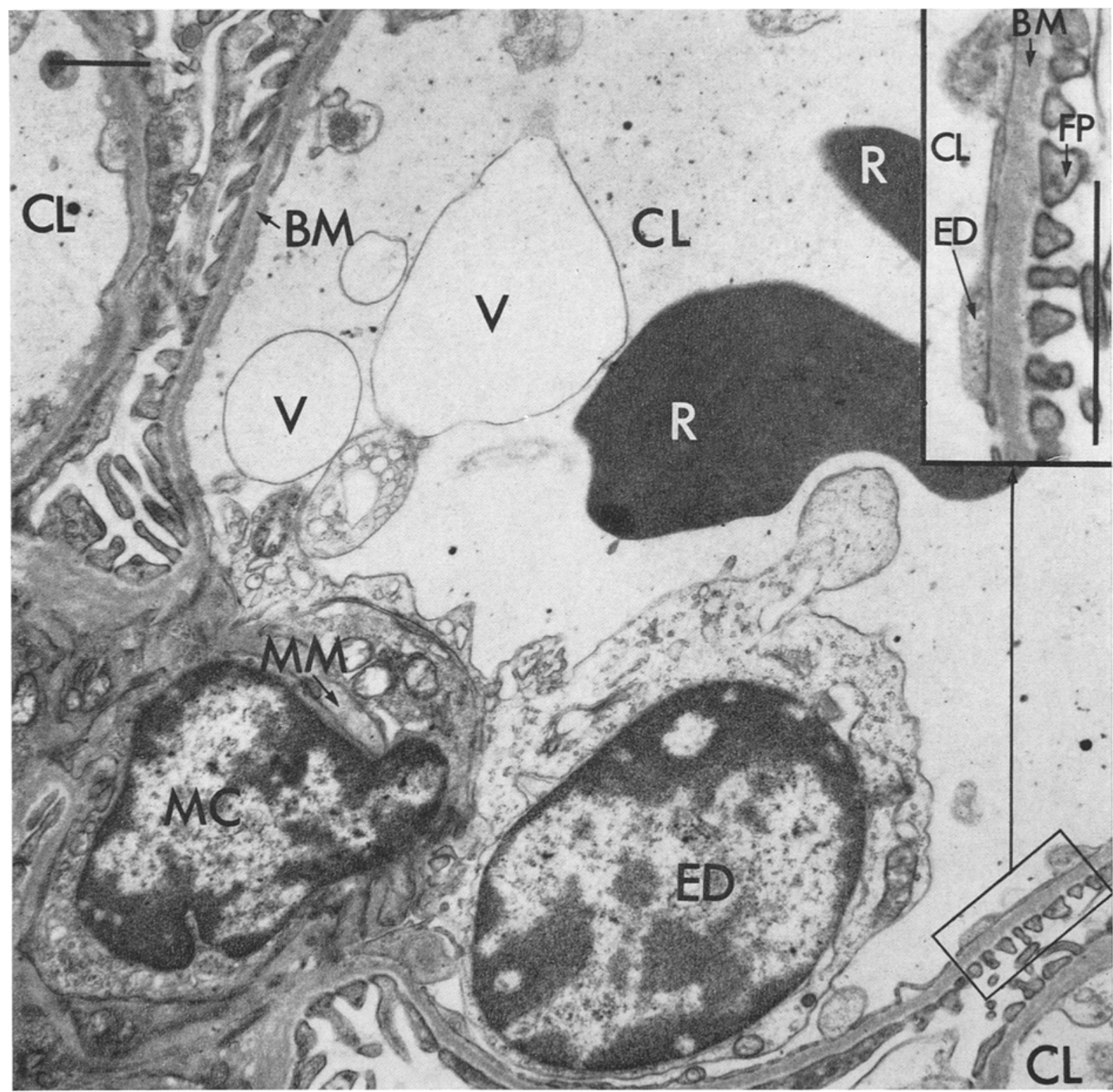

Fig. 7. Electron micrograph of part of a glomerulus in a young non-diabetic hamster (CS-E). The mesangial cells are embedded in the mesangial matrix. The basement membrane is thin and fairly uniform. The scale indicates $10000 \AA$

microscopy $[37,32,15,33,6,40,42]$. Tt has been reported that the glomerular changes that develop in these animals resembled more closely the diffuse type of glomerulosclerosis found in the human rather than the nodular type. However, some workers [10, 9, 39] have reported a nodular type of glomerular lesion in alloxanized dogs and in rabbits treated with cortisone, with and without alloxan.

The natural history of glomerulopathy associated with diabetes in animals is still controversial. It has been generally accepted that the mesangial cells and their matrix in the glomeruli are increased in the later stages. However, our findings of the thickening of the glomerular basement membrane, the mesangial cell alterations, decrease in the number of mesangial cell nuclei, and dissociation of the mesangium and the basement membrane with resultant coalescence or fusion of capillary loops differ from the observations of others. The thickening of the basement membrane of the glomeruli has been considered one of the early changes of diabetic glomerulopathy by many investigators from the study of experimental animals $[42,9]$ and of human biopsy material $[7,13,12,8,29]$. However, KrMmelstiel and his co-workers [25, 24] have reported that all glomeruli of the diabetic kidney do not necessarily show the thickening, stating that "the 


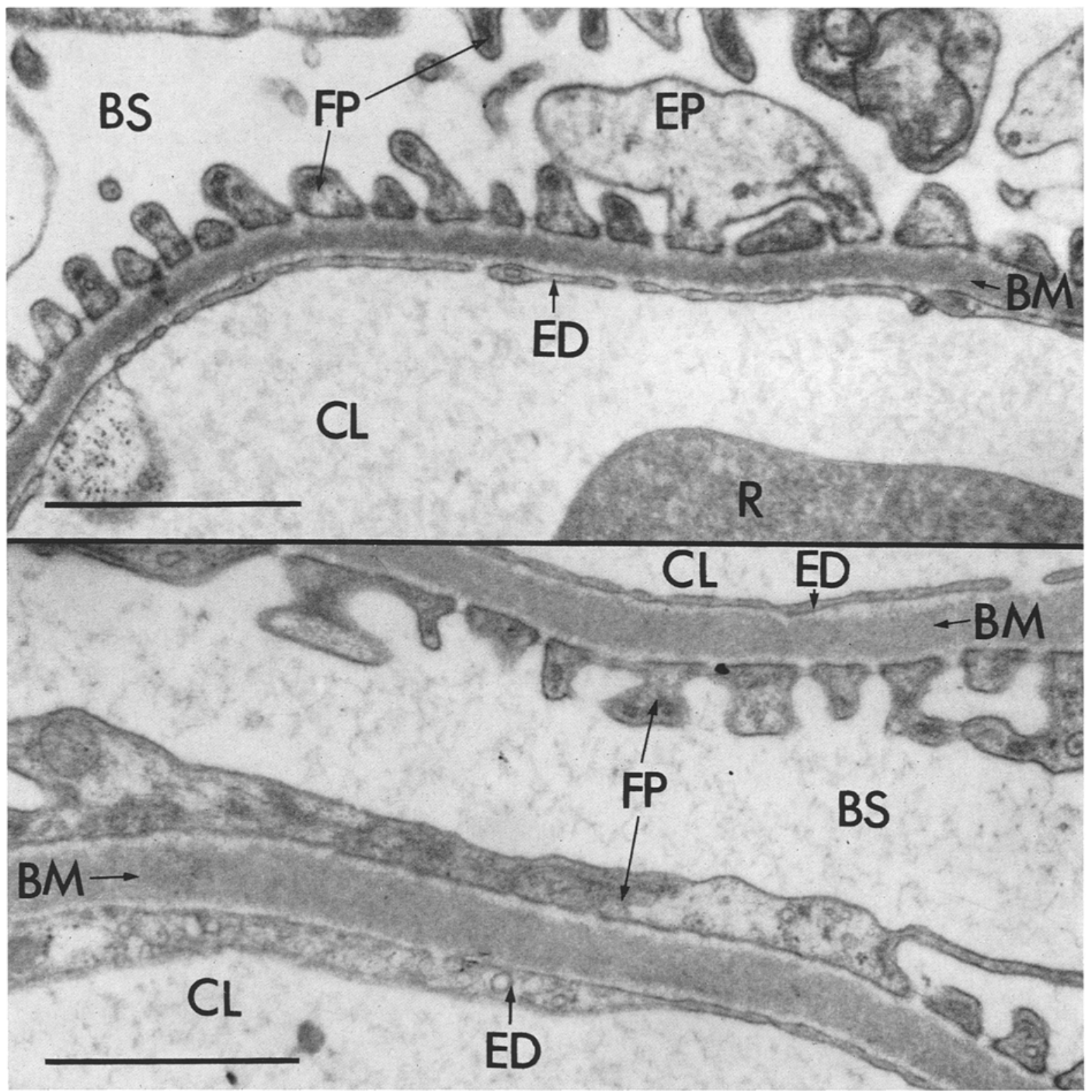

Fig. 8. Flectron micrograph of the basement membrane in a young non-diabetic hamster (upper) and an old non-diabetio hamster (lower) (8-2 and CS-3). The seale indicates $10000 \AA$

generally accepted concept of invariable and early thickening of peripheral basement membrane is based upon observations of irregular focal increase of width which cannot be quantitated and compared with the normal variation of thickness" [24]. HANSEN [20] has also reported results similar to those of KIMMELSTIEL in his study of jurenile diabetic patients. In contrast, thinning of the peripheral basement membrane has been reported only by SAKAGUCHI [44] in a 56-year-old diabetic patient.

From our observations there is no thickening of the basement membrane in the early stage of early. onset diabetes, and the mean thickness is rather less than that seen in the non-diabetic hamster of comparable age. Actually, thinning of the membrane may occur where the capillaries show marked dilatation. In the intermediate and late stages of early-onset diabetes and intermediate and late-onset diabetes the basement membrane has both thin and thick portions with a biphasic distribution curve of thickness. These observations concur essentially with those of KIMmELSTIEI [25]. Various other types of structural changes in the basement membrane of diabetic glomerulopathy have been reported: i.e., membranous transformation, lamination, high density droplets, and decreased density. 


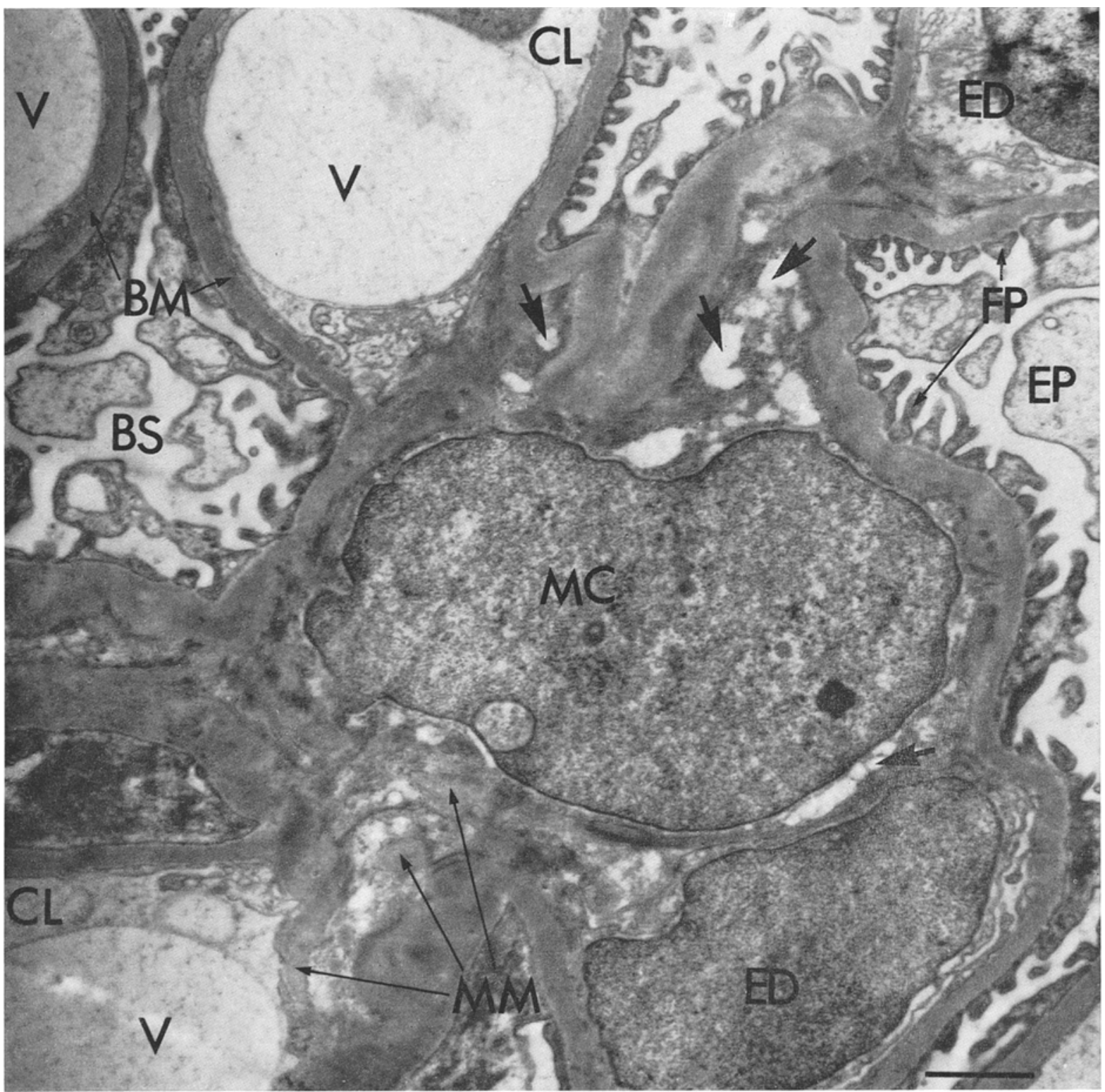

Fig. 9. Electron micrograph of a glomerulus of an aged non-diabetic hamster (CS-3). Increased vacuolization of mesangial cells is shown, the basement membrane is thickened, but the thickness is uniform. The scale indicates $10000 \AA$

Among the structural changes seen in all our diabetic hamsters was the "mossy" appearance, particularly on the epithelial side of the basement membrane. A similar finding is also seen in the aged animal. Although such changes in the basement membrane of the diabetic hamster were similar to those seen in nephrotic syndrome in humans, the diabetic hamster did not have proteinuria, suggesting that such changes are not necessarily associated with proteinuria.

An increase in the number of mesangial cells and in the amount of their matrix has been observed by others to be early changes in experimental diabetic glomerulopathy $[10,9]$ and in study of human biopsy material $[12,8,29,25,24]$; but to date there has been no detailed report of the associated characteristic findings of increased numbers of vesicles, multivesicular bodies, vacuoles and disorganization of mitochondria in the mesangial cells. SAKAGUOHI [44], however, has reported vacuolization in the mesangial cells together with increase in mesangial matrix in patients who had had diabetes for 7 years. Our observations during the early stage of early-onset diabetes showed marked alterations of the mesangial cells with first a decrease and then an increase in the amount of mesangial matrix. These changes were observed in all diabetic animals, although the degree of change differed in each stage. There followed a dissociation of the mesangium and the basement membrane with resul- 


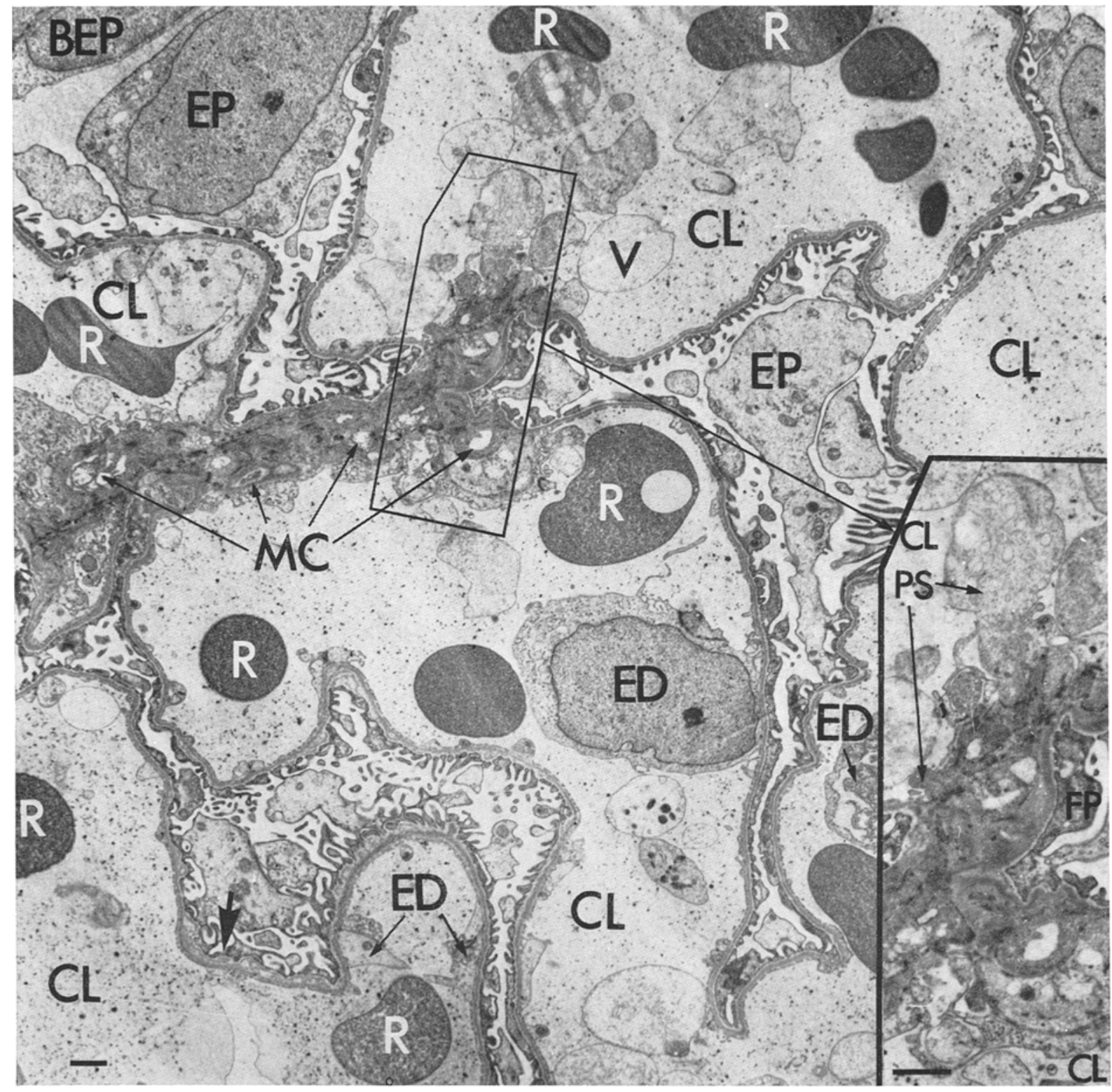

Fig. 10. Electron micrograph showing changes in the hamster glomerulus in the early stage of early-onset diabetes (C-3). Marked mesangial cell alterations (see text) are present. Cystic dilatation of the capillary is seen. The basement membrane is thick and some parts (arrow) of the capillary basement membrane appear mossy. Small electron dense material, presumably lipid, appears within the capillary loops. The scale indicates $10000 \AA$

tant fusion or coalescence of the capillary loops and apparent reduction in the number of loops. The postulated sequence of events leading to the coalescence of the capillary was suggested by the following indirect evidence. 1. A bridge-like fusion of capillary loops was frequently observed within the dilated capillary. 2. There was less mesangial matrix and fewer mesangial cell nuclei found in such altered glomeruli. 3 . If the observed dilatation was confined to a single capillary, there should be changes in the foot processes; such changes were not observed. 4 . The absence of compressed capillary loops would indicate that there was a true decrease in the number of loops. 5. The dilated capillary was cystic in shape rather than "bal- loon-like" or aneurysmal (based upon reconstruction model of half a glomerulus and other serial sections).

Such dilatations of the capillary loops subsequent to mesangial changes have not previously been thought to be characteristic findings in the natural course of diabetic glomerulopathy. However, GELLMAN [16] recently described capillary dilatation in the very early stage of diabetic glomerulopathy in the human, before any definite evidence of glomeruloselerosis was present. Also Hückex [21] reported in 1938 the cystic elastic dilatation of the glomerular capillary in a 77 year-old patient with diabetes of 30 years' duration. He postulated that this cystic dilatation was a precursor of the nodule of diabetic glomerulopathy. Later, 


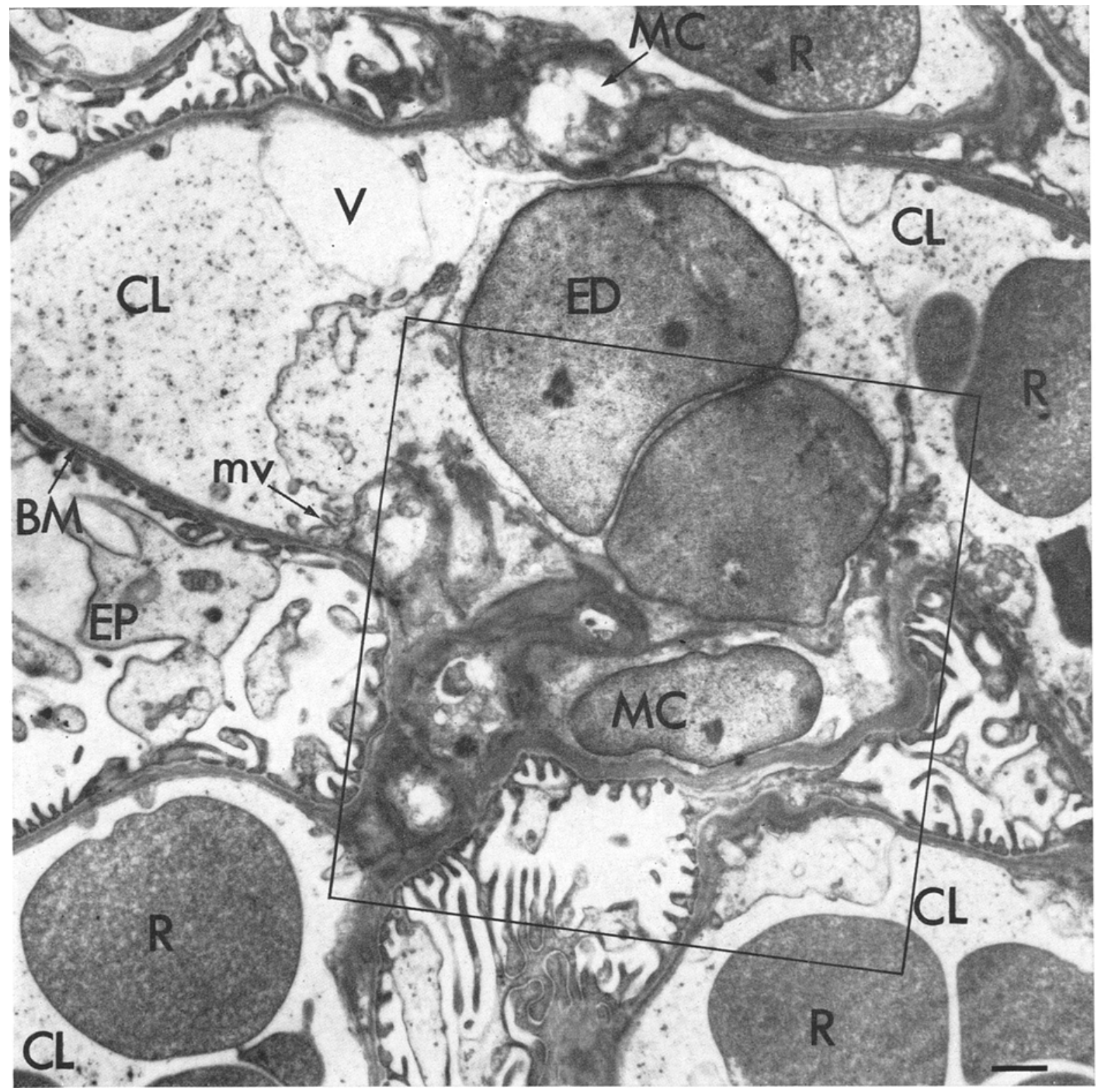

Fig. 11. Electron micrograph of a hamster glomerulus with early-onset diabetes in the early stage (C-3). Severe mesangial cell alterations and marked capillary dilatation are present as shown in the previous micrograph (see text). Different types and degrees of mesangial alterations are present. The seale indicates $10000 \AA$

ALLEN [1] and ANDERson [2] also observed the cystic glomerular capillary dilatation in the diabetic patient, although the description and interpretation of each investigator was slightly different. On the other hand, in spontaneous diabetic glomerulopathy, LAwE [31] did report quite marked capillary dilatation in the early stage of a diabetic Chinese hamster, but he considered that neither this finding nor cystic dilatation of the fused capillary was characteristic changes of early diabetic glomerulopathy.

Similar findings have been reported by KITAmura [26], Sakaguchi [43] and Suzuki [46] as a "mesangiolysis" in the kidney glomeruli of the rabbit that had been poisoned by habu snake venom. Initially there was a decrease in the amount of the mesangial matrix, vacuolization and pseudopod formation of the mesangial cells, and finally portions of the mesangial area broke down and two or more separate capillary loops were fused together to form a cystic dilated capillary. SAKAGUCHI [26] has also reported similar findings in the recovery process of experimental glomerulonephritis. According to our observations, however, this phenomenon did not occur in the middle of the mesangium (mesangiolysis), but represented a dissociation of the basement membrane and the mesangium. This dissociation seemed to occur only in the peripheral 


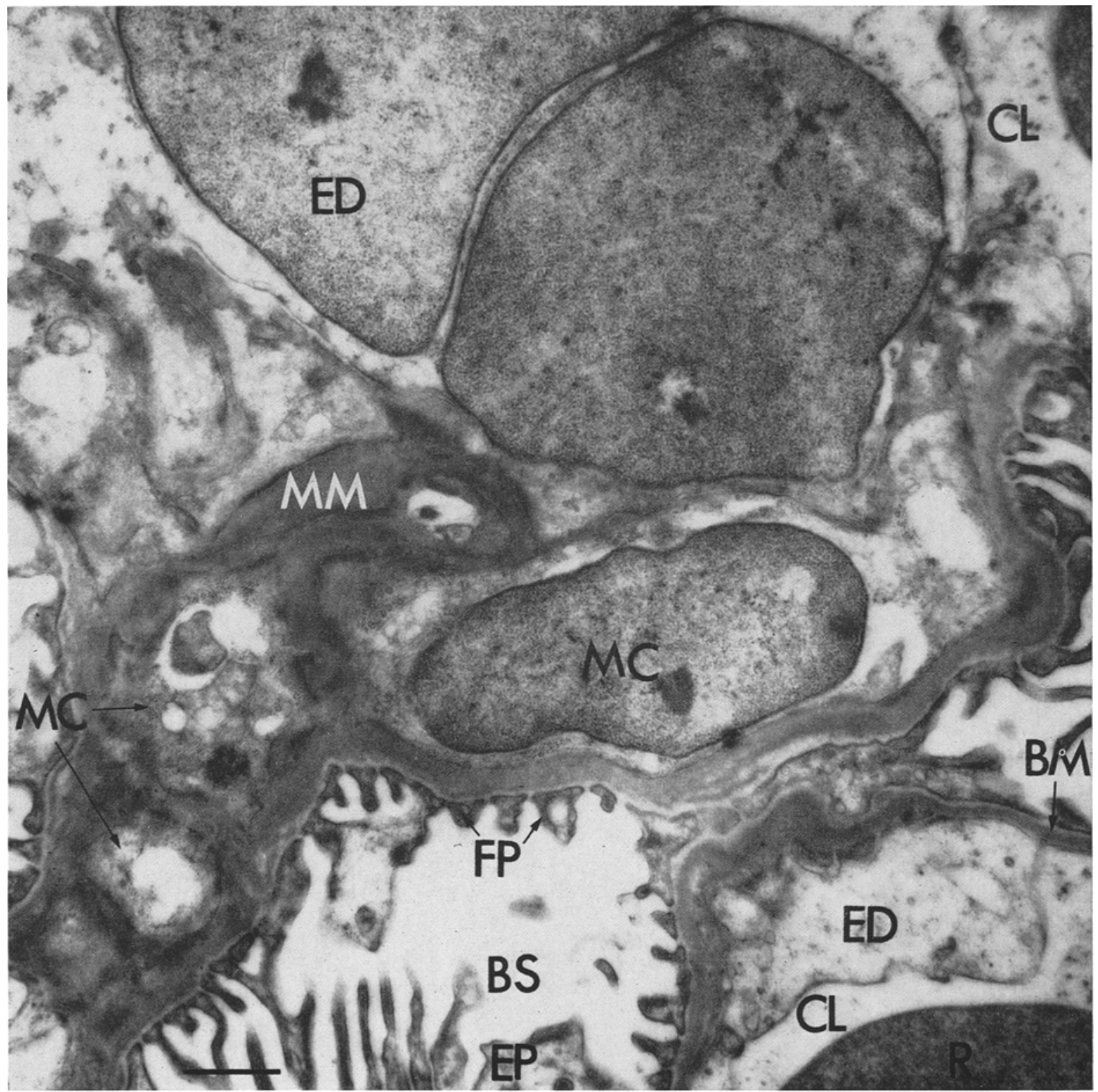

Fig. 12. A higher-power view of the mesangial portion of the former electron micrograph (Fig. 11). The highly vacuolated mesangial cells are shown. The scale indicates $10000 \AA$

portion of the glomerular capillaries; the significance of this observation is not yet clear.

It appeared that the marked dilatations and coalescence of capillaries in the glomeruli of the kidney of young hamsters without significant nephrotic changes were characteristic findings of the early stage of diabetic glomerulopathy, and that such changes were characteristically disproportionately marked in any later stage of the disease and precede any increase in mesangial matrix. We feel that such changes were important in the development of diabetic glomerulopathy. It is of interest that in another form of microangiopathy in the diabetic, that of retinopathy, early change in a structural cell is associated with capillary dilatation. Cogav et al. [11] have described alterations in the mural cells, which appeared to have a muscular function in controlling capillary blood flow. It seemed quite possible that an early metabolic change in both the mural and mesangial cells in diabetes leads to the development of the typical lesions.

Finally, fully developed Kimmelstiel-Wilson nodules were not seen at any stage of diabetes despite the marked thickening of the mesangium.

Acknowledgements. We are grateful to Professor FredERICK DUNIHUE of the Department of Anatomy for his guidance and criticism and for making available to 


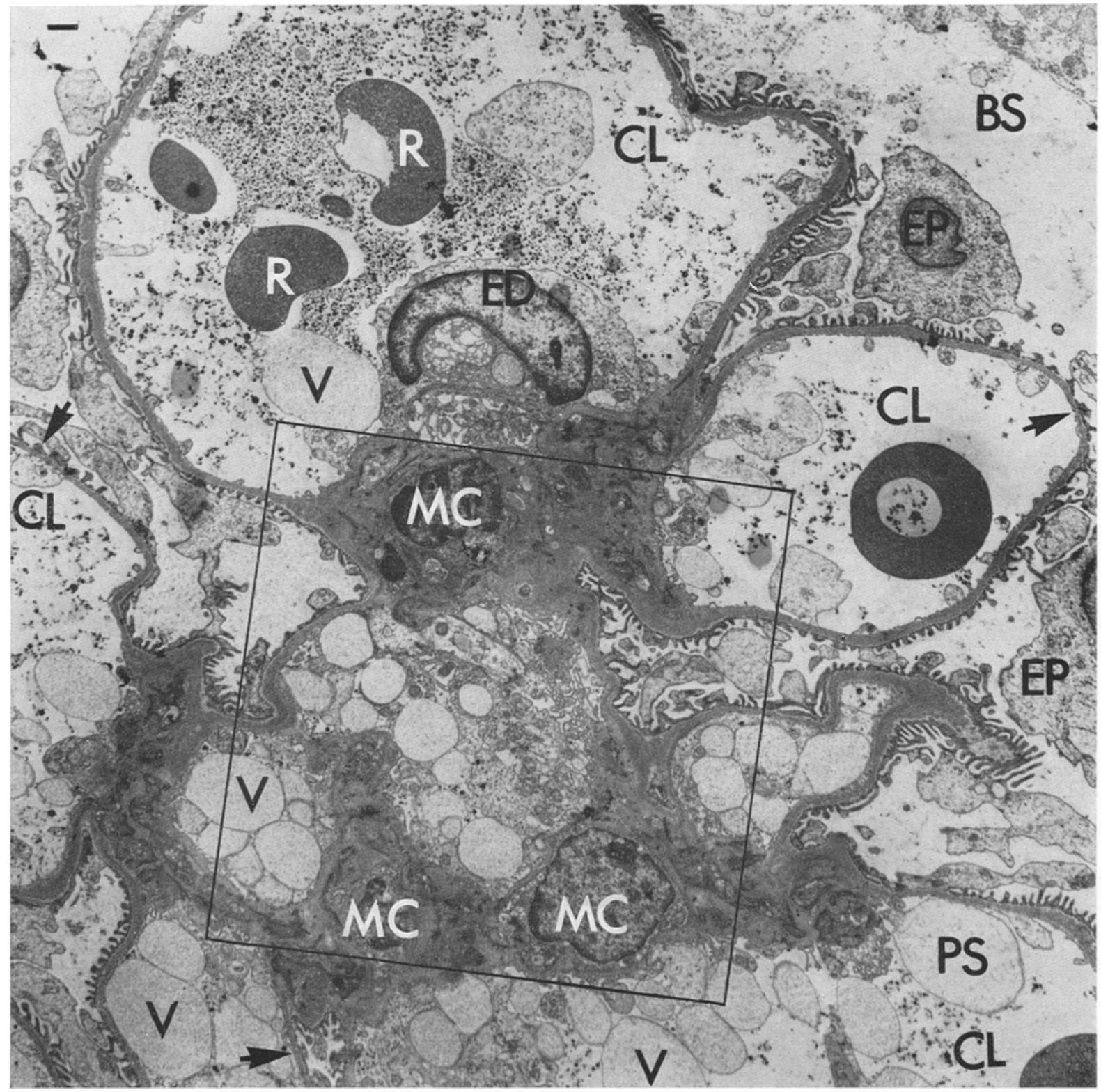

Fig. 13. Electron micrograph showing the glomerulus of the intermediate stage of early-onset diabetes (D-2), Dilatation of the capillary loops, alterations of the mesangial cells and endothelial cells, increased mesangial matrix, heavy electron density small material and many vacuoles in the capillary lumen are shown. A highly vacuolated capillary lumen boxed in the middle is in an unaecountable location in that the mesangium surrounds nearly the entire capillary. The basement membrane is both thin (arrow) and thick and it has a mossy appearance. The scale indicates $10000 \AA$

us the facilities of his electron microscopy laboratory. M. A. Lorenz, R. N., and Renzo Nylander, B. S, contributed to the care and breeding of the hamsters. One of us (T.S.) was supported during the study by a grant from the Cleveland Diabetes Association (Ohio, U.S.A.) and by U.S. Public Health Service grant AM-10254 The hamster colony was supported by USPHS grant $\mathrm{AM}-05748$.

\section{References}

[1] ALLEN, A.C.: So-called intercapillary glomerulosclerosis - a lesion associated with diabetes mellitus. Arch. Path. 32, 33-51 (1941).
[2] Anderson, G.S.: The pathogenesis of diabetic glomeruloselerosis. J. Path. Bact. 67, 241-245 (1954).

[3] Andrew, W., and D. Pruetr: Senile changes in the kidneys of Wistar Institute rats. Amer. J. Anat. 100, $51-69(1957)$.

[4] Arataki, M.: On the postnatal growth of the kidney with special reference to the number and size of the glomeruli (albino rat). Amer. J. Anat. 36, 399-436 (1926).

[5] Ashworth, C.T., R.R. Erdmand and N.J. Arnold: Age changes in the renal basement membrane in rats. Amer. J. Path. 36, 165-179 (1960).

[6] Beaser, S.G., M.F. Sak, G.W. Donaldson, R.J. MoLaUghrin and S.C. Sommers: Alloxan diabetes in the golden hamster, Mesocricetus auratus. II. 


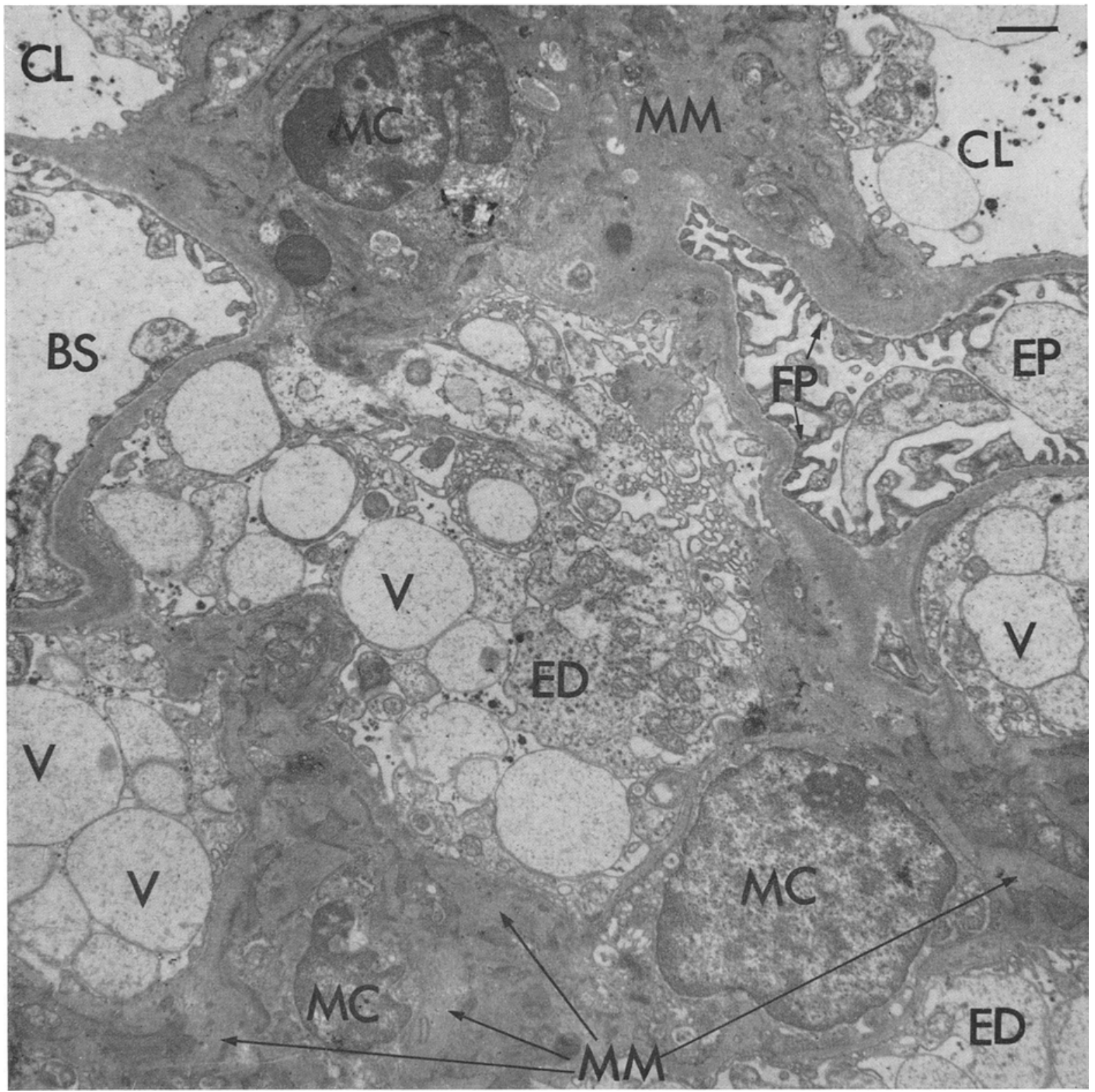

Fig. 14. A higher-power view of the former micrograph (Fig. 13). Marked endothelial cell ehanges and mesangial cell alterations together with increased mesangial matrix are seen. The scale indicates $10000 \AA$

Glomerulosclerosis and its relation to diabetes regulation. Diabetes 13, 49-53 (1964).

[7] Bergstrand, A., and H. BuCHT: Electron microscopic investigations on the glomerular lesions in diabetes mellitus (diabetic glomeruloselerosis). Lab. Invest. 6, 293-300 (1957).

[8] Bloopworth, J.M.B.: Diabetic microangiopathy. Diabetes 12, 99-114 (1963).

[9] - : Experimental diabetic glomerulosclerosis. IT. The dog. Arch. Path. 79, $113-134$ (1965).

[10] - , and G.J. Hamwr: Experimental diabetic glomerulosclerosis. Diabetes 5, 37-43 (1956)

[11] Cogan, D.G., and T. KUWabara: Capillary shunts in the pathogenesis of diabetic retinopathy. Diabetes $12,293-300(1963)$.
[12] DaChs, S., J. ChURG, W. MaUtNerr and E. GrishIMAN: Diabetie nephropathy. Amer. J. Path. 44, $155-168(1964)$.

[13] Farquhar, M. G., J. Hopper, Jr. and H. D. Moor: Diabetic glomerulosclerosis: Electron and light microscopic studies. Amer. J. Path. 35, $721-753$ (1959).

[14] - , and G.E. PAIADE: Functional evidence for the existence of a third cell type in the renal glomerulus. Phagocytosis of filtration residues by a distinctive "third cell". J. cell. Biol. 13, 55-87 (1962).

[15] Foglia, V.G., R.E. Mancint and A.F. Cardeza: Glomerular lesions in the diabetic rat. Arch. Path. 50, $75-83(1950)$.

[16] Gelmiman, D.D., C.L. Pirani, J.F. Soothild, R.C. MUEHRCKE and R.M. KARK: Diabetic nephropathy. 


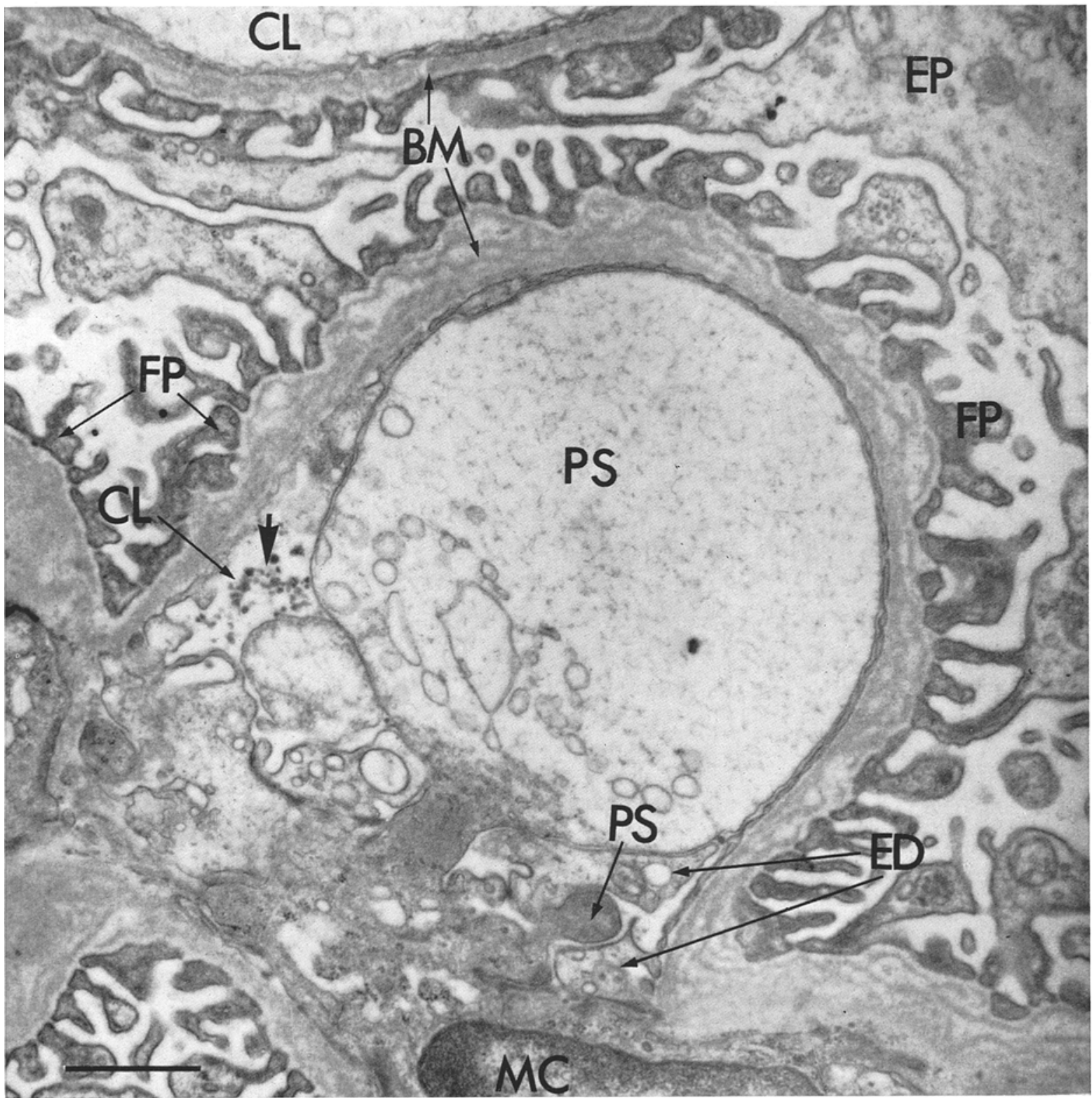

Fig. 15. A large pseudopod of mesangial cells and mossy appearance of the basement membrane are shown in this eleetron micrograph of a hamster glomerulus with earIy-onset diabetes in the intermediate stage (D-2). Some of the basement membrane (upper portion) is still thin. An arrow points to the heary electron dense material, presumably lipid. The scale indicates $10000 \AA$

A clinical and pathologic study based on renal biopsies. Medicine 38, 321-367 (1959).

[17] Grein, M.N., G. Yerganlan and H.J. Gagnon: Prediction of spontaneous hereditary diabetes melli. tus in Chinese hamster by means of elevated alpha-2 serum levels. Nature (Lond.) 197, 396 (1963).

[18] Gude, W.D., and A.C. UPToN: A histologic study of spontaneous glomerular lesions in aging RF mice. Amer. J. Path. 40, 699-709 (1962).

[19] Gutrman, P.H., and H.I. KoHv: Progressive intercapillary glomerulosclerosis in the mouse, rat, and Chinese hamster, associated with aging and $x$-ray exposure. Amer. J. Path. 37, 293-307 (1960).

[20] HANSEN, R.Ø.: A quantitative estimate of the peripheral glomerular basement membrane in recent juvenile diabetes. Diabetologia 1, 97-100 (1965).
[21] HÜCKEL: Eigenartige Glomerulusveränderungen bei benigen Nephrosklerose. Verh. dtsch path. Ges. 31, 392-397 (1938).

[22] Kimmenstiel, P.: Glomerular changes in arteriosclerotic contraction of the kidney. Amer. J. Path. 11, $483-495$ (1935).

[23] -, and C. WILSON: Intercapillary lesions in the glomeruli of the kidney. Amer. J. Path. 12, 83-97 (1936).

[24] -, G. Osawa and J. Beres: Glomerular basement membrane in diabetics. Amer. J. clin. Path. 45, $21-31(1966)$.

[25] -, O.J. Krm and J. Beres: Studies on renal biopsy specimens, with the aid of the electron microscope. I. Glomeruli in diabetes. Amer. J. elin. Path. 38, $270-279(1962)$. 




Fig. 16. Electron micrograph of a hamster glomerulus with early-onset diabetes in the late stage (2-2). Note the increase in the number of mesangial cells and in the amount of their matrix along with mesangial cell alterations. In the upper portion (Ex) there are changes which could be interpreted as exudative in nature. The lumen in the upper left (*) may be a false lumen (subendothelial space), as there is no endothelial cell lining (arrow)

[26] Kitamura, W., T. Hashiguchi, R. Hamaguchi and M. OYAMA: Pathological study on the snake poisoning. Nichibyokaishi 46, 355 (1957).

[27] KoHN, H.T., and P.H. GUTTMaN: Life span, tumor incidence, and intercapillary glomerulosclerosîs in the Chinese hamster (Cricetulus griseus) after wholebody and partial-body exposure to x-rays. Radiat. Res. 21, 622-643 (1964).

[28] KuRTz, S.M.: "The Kidney". In Electron Microscopic Anatomy. Edited by S.M. Kurtz pp. $239-265$. New York: Academic Press 1964.

[29] LanNigait, R., J.D. BLATNEY and D.B. Brewer: Electron microscopy of the diffuse glomerular lesion in diabetes mellitus with special reference to early changes. J. Path. Bact. 88, 255-261 (1964).

[30] LatTa, H., A.B. MaUnsbauh and S.C. Madden:
The centrolobular region of the renal glomerulus studied by electron microscopy. J. Ultrastructure Research 4, 455-472 (1960).

[31] LAwE, J.E.: Renal ehanges in hamster with hereditary diabetes mellitus. Arch. Path. 73, 166-174 (1962).

[32] Lukens, F.D.W., and F.C. Dohar: Experimental pituitary diabetes of five years duration with glo. meruloselerosis. Arch. Path. 41, 19-24 (1946).

[33] Mann, G.V., J.W. Goddard and L. Adams: The renal lesions associated with experimental diabetes in the rat. Amer. J. Path. 27, 857-869 (1951).

[34] Merer, H.: "Hereditary diabetes mellitus in the Chinese hamster: Certain aspects of prediabetic state in the hamster and reference to the obese-hyperglycemic mouse". From: Small Blood Vessel Involve- 


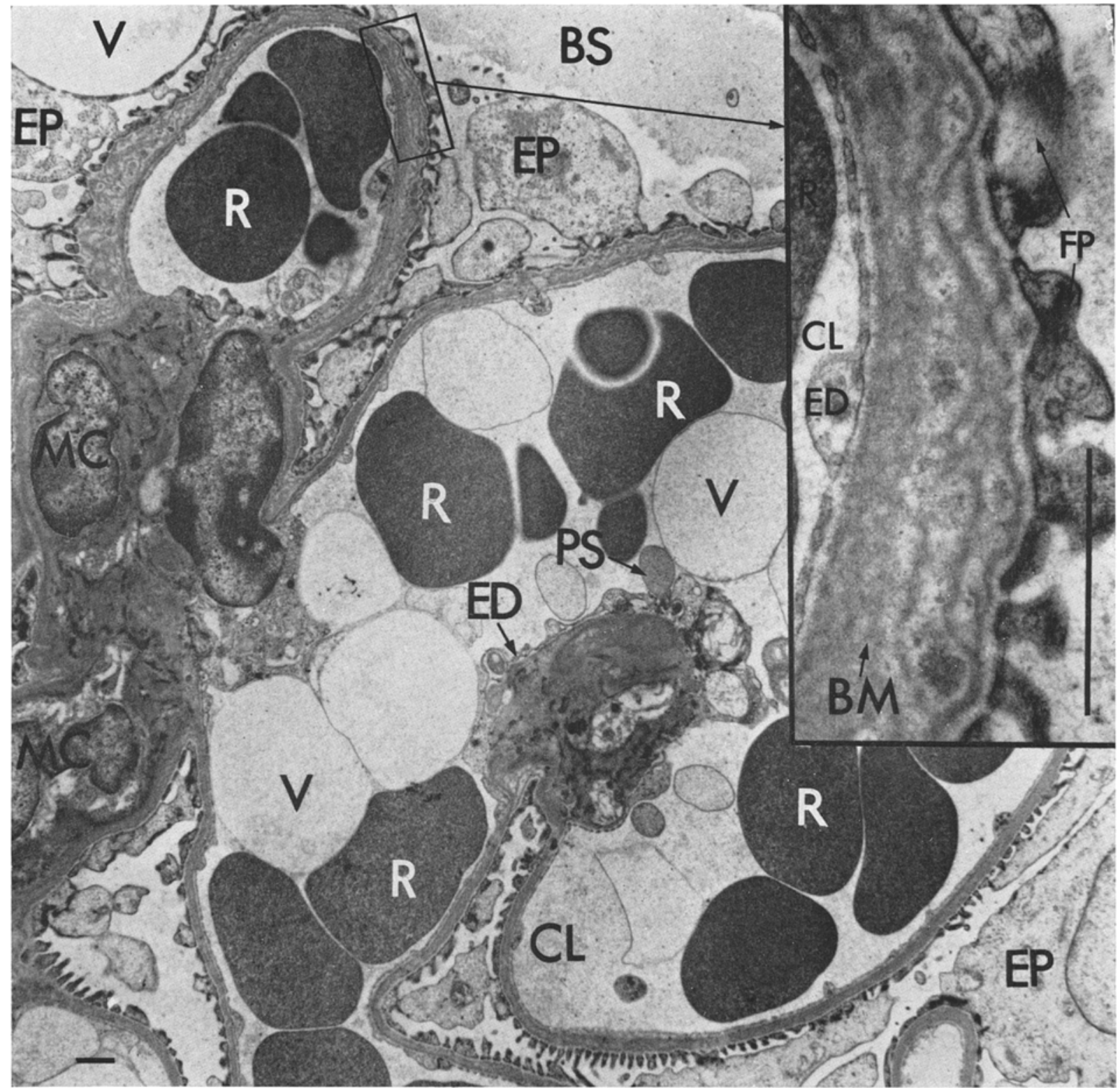

Fig. 17. Electron micrograph of a hamster glomerulus with early-onset diabetes in the late stage (2-2). Note the increase in the number of mesangial cells and their matrix and alterations of mesangial cells along with capillary dilatation. The basement membrane in the large capillary loops is not thick, but in the small loops it is thick. The mossy appearance of the basement membrane can be seen. The scale is $10000 \mathrm{~A}$

ment in Diabetes Mellitus. Siperstein, M.D., and A.R. Colwell, Sr., and K. Meyer, Eds. pp. 303-308. Washington, D.C.: American Institute of Biological Science 1964 .

[35] -, and G.A. YaRGANIAN: Spontaneous hereditary diabetes mellitus in Chinese harnster (Cricetulus griseus). I. Pathological findings. Proc. Soc. exp. Biol. 100, 810-815 (1959).

[36] - - Spontaneous diabetes mellitus in the Chinese hamster (Cricetulus griseus). II. Findings in the offspring of diabetic parents. Diabetes 10, 12-18 (1961).

[37] _ - Spontaneous hereditary diabetes mellitus in the Chinese hamster (Cricetulus griseus). III. Maintenance of diabetic hamster colony with the aid of hypoglycemic therapy. Diabetes 10, 19-21 (1961).
[38] Moore, R.A., and L.M. Helliman: The effect of unilateral nephrectomy on the senile atrophy of the kidney in the white rat. J. exp. Med. 51, 51-57 (1930).

[39] Moran, T.J., S.M. Kurtz and J.J. VAzQUEZ: Diabetic and cortisone induced ronal lesions. A morphologic and immunohistochemical study. Lab. Invest. 11, 240-254 (1962).

[40] Orskov, H., T. Steien Olsen, K. NIEtsen, O.J. RAFAelsEN and $K$. LundBafK: Kidney lesions in rats with severe long-term alloxan diabetes. I. Influence of age, alloxan damage, and insulin administration. Diabetologia 1, 172-179 (1966).

[41] RHodin, J.A.G.: "Structure of the Kidney". In "Diseases of the Kidney". Edited by M.B. STrauss 


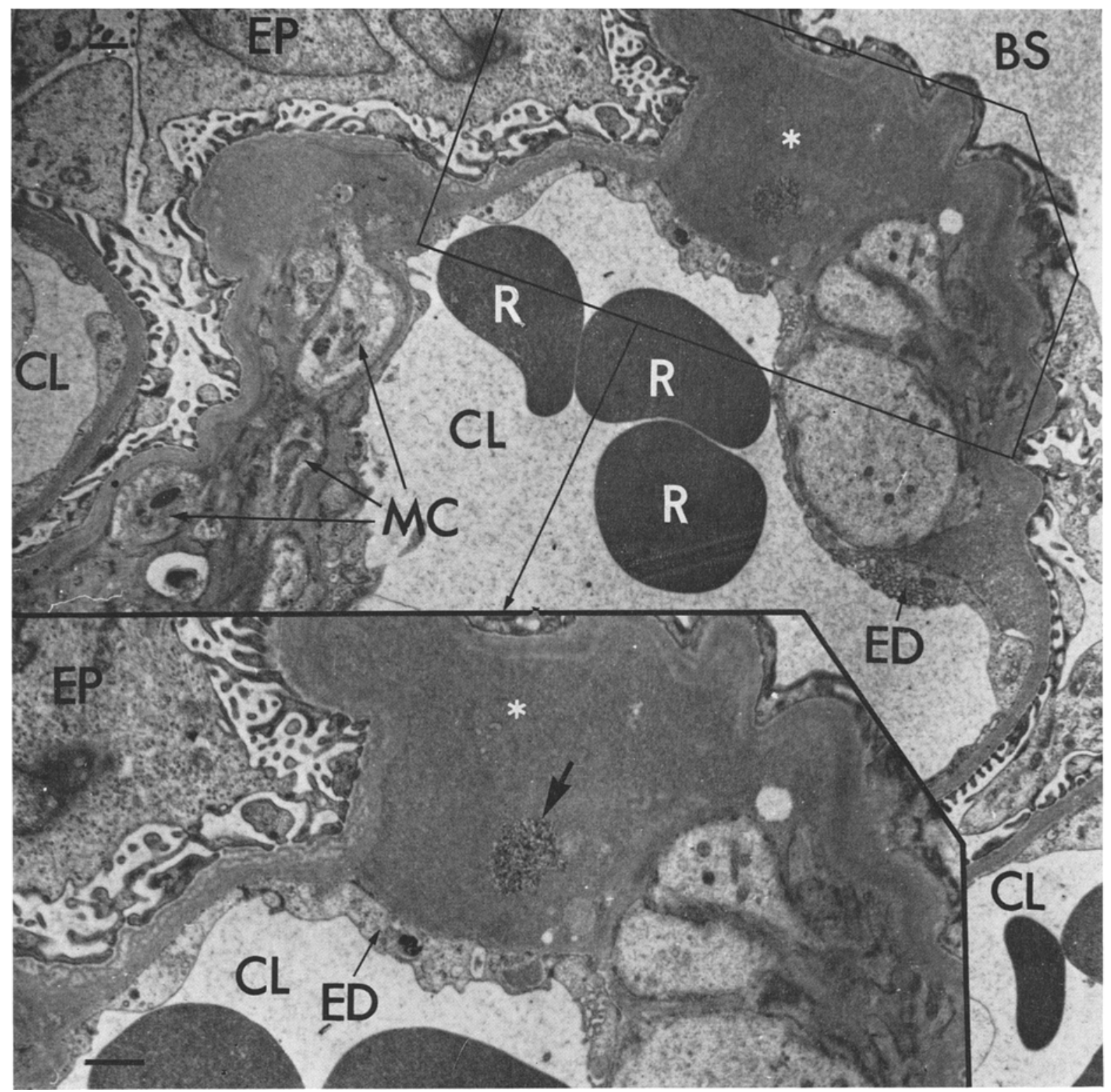

Fig. 18. Heavy proteinous deposits ean be seen in the subendothelial space in this electron micrograph of a hamster glomerulus with early-onset diabetes, late stage (2-2). Heavy density material(arrow) can be seen in these deposits. The scale is $10000 \AA$

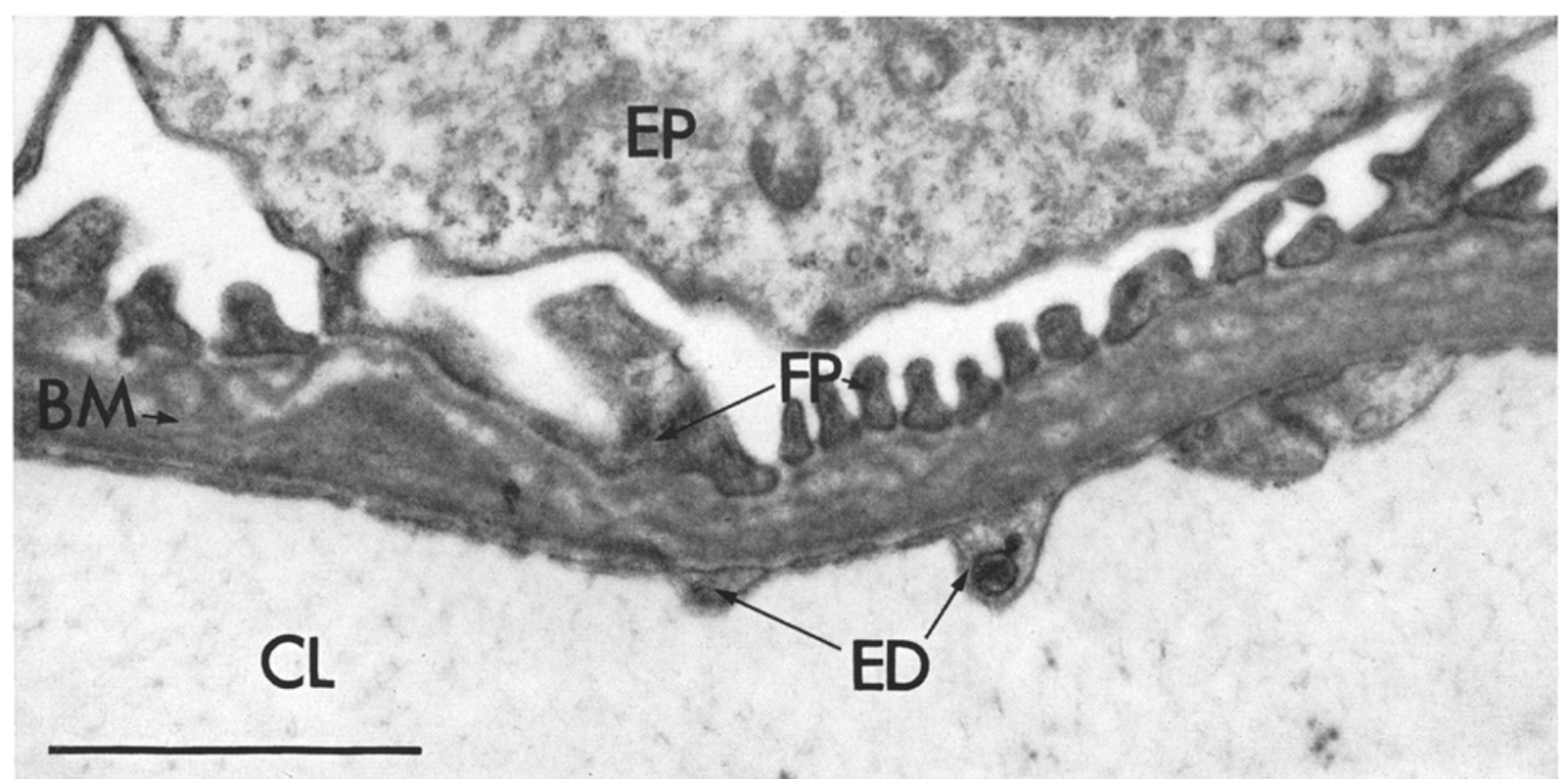




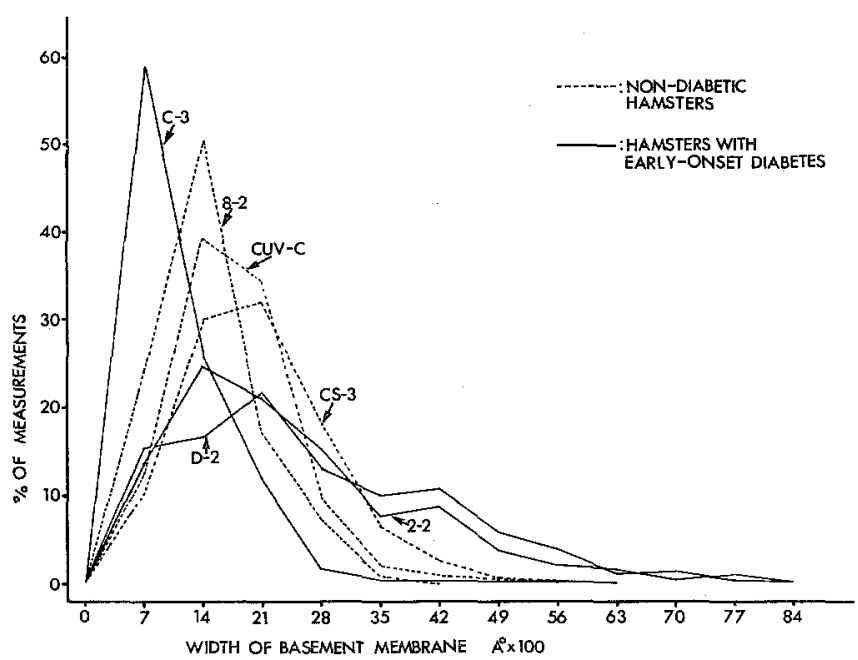

Fig. 20. The distributition curves of the thickness of the basement membrane in non-diabetic hamsters (8-2, CUV-C, and CS-3) as compared with the hamsters with early-onset diabetes at different stages



Fig. 21. The distribution curves of the thickness of the basement membrane of a hamster with early-onset diabetes (CD-2) and of the non-diabetic littermates of a diabetic hamster (6-2)

and L.G. WELT. Boston, Little Brown and Co., pp. $1-29,1963$.

[42] Ricketis, H.T., C.E. Test, E.S. Pertersen, H. Lints, N. Tupikova and P.E. Steinter: Degenerative lesions in dogs with experimental diabetes. Diabetes $8,298-306(1959)$.

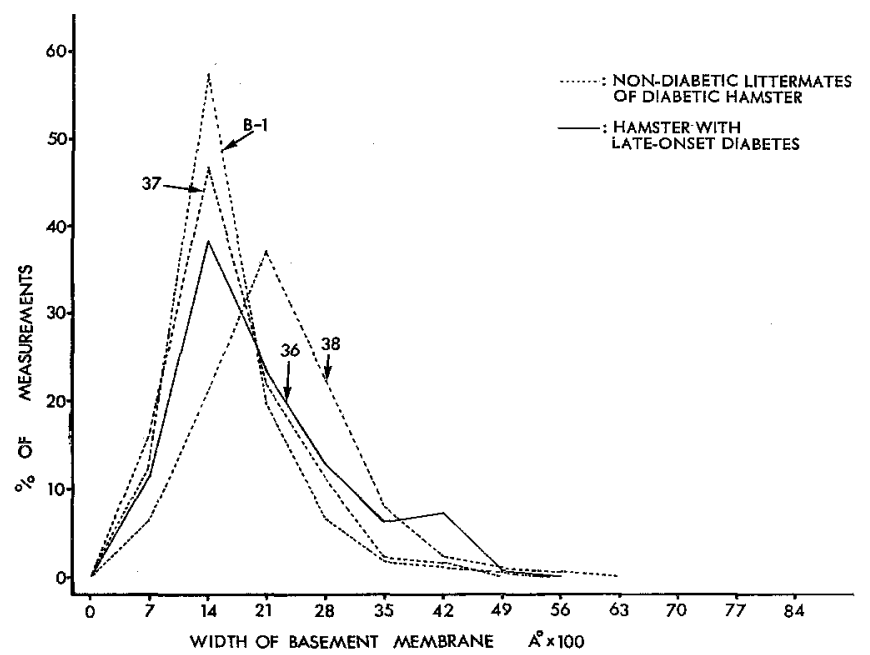

Fig. 22. The distribution curves of the thickness of the basement membrane of the hamster with late-onset diabetes (36) and non-diabetis litter-mates of diabetic hamsters $(37, \mathrm{~B}-1,38)$

[43] Sakaguchi, H., and S. Kawamora: Electron microscopic observations of the mesangiolysis. The toxio effects of the "Habu snake" venom on the renal glomerulus. Keiô J. Med. 12, 99-112 (1963).

[44] -, Y. Suzukr and T. RYI: Electron microscopic. study of the kidney. $V$. Diabetic glomerular changes. Sôgôrgaku 16, 541-553 (1959)

[45] Sims, E.A.H., and B.R. Landad: Diabetes mellitus in the Chinese hamster. I. Metabolic and morphologic studies. Diabetologia 3, 115-123 (1967).

[46] Suzuki, Y., J. Churg, E. Grishman, W. Mautner and S. DAcHs: The mesangium of the renal glomerulus. Electron microscopic studies of pathologic alterations. Amer. J. Path. 43, 555-578 (1963).

[47] Yamada, E.: The fine structure of the renal glomerulus of the mouse. J. biophys. biochem. Cytol., 1, $551-566$ (1955).

[48] Yergantak, G.: "Spontaneous diabetes mellitus in the Chinese hamster, Cricetulus griseus. Current trends and projected views". In "On the Nature and Treatment of Diabetes". LEIBEL, B.S., and G. A.WRENshatr, Eds. Amsterdam, Excerpta Medica Foundation pp. $612-627.1965$.

[49] - The striped back or Chinese hamster, Cricetulus griseus. J. nat. Cancer Inst. 20, $705-727$ (1958).

George W. WeLSH, 3rd, M. D.

Metabolic Unit, Department of Medicine

University of Vermont College of Medicine Burlington, Vermont 05401

Responsible for the text: Prof. Dr. ALBERT E. REwold, Dept. of Biochemistry, University of Geneva, Switzerland. Responsible for advertisements: EdGar SeIdrar, 1 Berlin 31 (Wilmersdorf), Heidelberger Platz 3. Springer-Verlag, Berlin, Heidelberg, New Yorls. Printed in Germany by Buchdruckerei Georg Appl, Wemding/Schwaben. 